\title{
Evolution of a highly dilatant fault zone in the grabens of Canyonlands National Park, Utah, USA - integrating fieldwork, ground-penetrating radar and airborne imagery analysis
}

\author{
M. Kettermann ${ }^{1}$, C. Grützner ${ }^{2, a}$, H. W. van Gent ${ }^{1, b}$, J. L. Urai ${ }^{1}$, K. Reicherter ${ }^{2}$, and J. Mertens ${ }^{1, \mathrm{c}}$ \\ ${ }^{1}$ Structural Geology, Tectonics and Geomechanics Energy and Mineral Resources Group, RWTH Aachen University, \\ Lochnerstraße 4-20, 52056 Aachen, Germany \\ ${ }^{2}$ Neotectonics and Natural Hazards, RWTH Aachen University, Lochnerstraße 4-20, 52056 Aachen, Germany \\ ${ }^{a}$ now at: COMET; Bullard Laboratories, Department of Earth Sciences, University of Cambridge, Cambridge, UK \\ b now at: Shell Global Solutions International, Rijswijk, the Netherlands \\ ${ }^{c}$ now at: ETH Zürich, Zürich, Switzerland
}

Correspondence to: M. Kettermann (michael.kettermann@emr.rwth-aachen.de)

Received: 20 February 2015 - Published in Solid Earth Discuss.: 17 March 2015

Revised: 18 June 2015 - Accepted: 22 June 2015 - Published: 21 July 2015

\begin{abstract}
The grabens of Canyonlands National Park are a young and active system of sub-parallel, arcuate grabens, whose evolution is the result of salt movement in the subsurface and a slight regional tilt of the faulted strata. We present results of ground-penetrating radar (GPR) surveys in combination with field observations and analysis of highresolution airborne imagery. GPR data show intense faulting of the Quaternary sediments at the flat graben floors, implying a more complex fault structure than visible at the surface. Direct measurements of heave and throw at several locations to infer fault dips at depth, combined with observations of primary joint surfaces in the upper $100 \mathrm{~m}$, suggest a highly dilatant fault geometry. Sinkholes observed in the field as well as in airborne imagery give insights in local dilatancy and show where water and sediments are transported underground. Based on correlations of paleosols observed in outcrops and GPR profiles, we argue that either the grabens in Canyonlands National Park are older than previously assumed or that sedimentation rates were much higher in the Pleistocene.
\end{abstract}

\section{Introduction}

Understanding the structure of dilatant fractures in normal fault zones is important for many applications in geoscience. Reservoirs for hydrocarbons, geothermal energy and freshwater often contain dilatant fractures (e.g., Ehrenberg and Nadeau, 2005; Wennberg et al., 2008; Jafari and Babadagli, 2011). A better understanding of the internal structures of such fault zones is required to extrapolate fault geometries in typical reservoir depths below the industrial seismic resolution. This is especially complicated when failure structures of different generations and with different mechanical properties interact with each other.

In this paper we present a case study focusing on the spectacular grabens of the Needles fault zone in Canyonlands National Park, Utah, USA (field photographs Fig. 1a-c), a fault array that reactivates two preexisting major joint sets. The area is well known as a sandstone reservoir analogue, and sedimentary rocks and soil are well exposed due to the semiarid climate. Estimates of the beginning of graben formation vary from $60-80 \mathrm{ka}$ (based on the dating of sediments in deep open fissures; Biggar and Adams, 1987) to $1.4 \mathrm{Ma}$, which is the estimated time of incision of the Colorado River (SchultzEla and Walsh, 2002). Present-day motions are known from interpretation of interferometric synthetic aperture radar (InSAR) data (Furuya et al., 2007). Reheis et al. (2005) were able to date Quaternary strata deposited during formation 


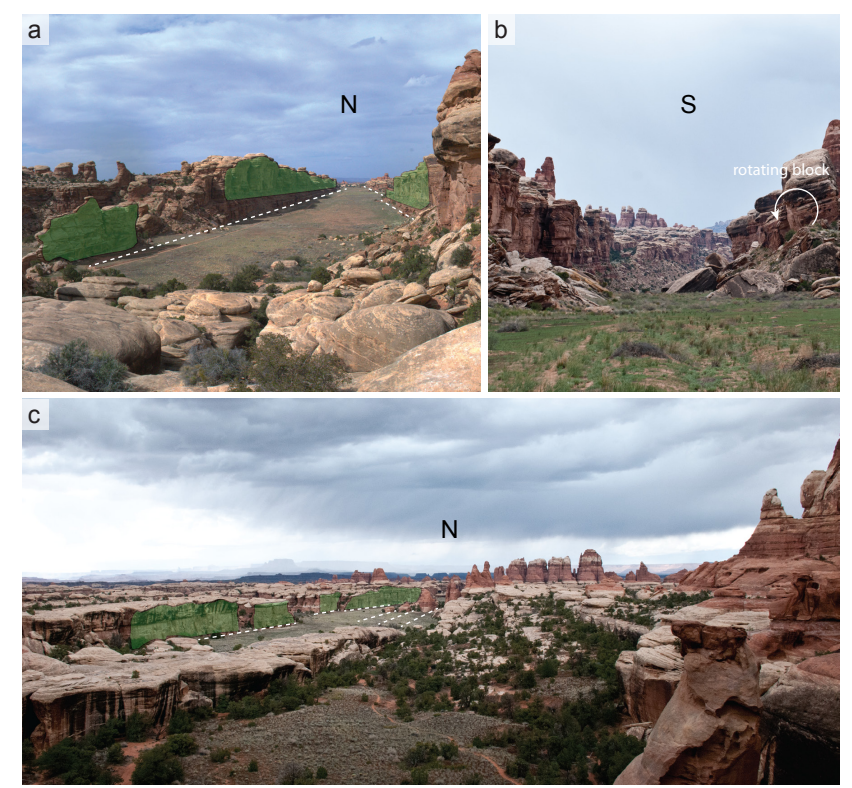

Figure 1. (a) Field photograph from the Devil's Lane relay facing north. (b) Northern Cyclone Canyon looking south. (c) View over the southern part of Devil's Pocket looking north. These photographs show the typical caps of the White Cedar Mesa sandstone, inferred faults (dashed lines) along vertical joint surfaces (colored in green) that are typical for this region. A joint set parallel to the faults is clearly visible. In (b) a block rotating into the graben due to reactivation of a joint by underlying faulting is shown in the west.

of the grabens. These studies show that the grabens of the Canyonlands are an active fault zone with syntectonic sedimentation. The goal of this study is to better understand the coupling between deformation, erosion and deposition in such an active system, as well as to gain insights into the internal structure of dilatant fracture systems. To this end, we combine detailed field analyses with ground-penetrating radar and remote-sensing data.

\section{The Needles fault zone}

The Needles fault zone is located in Canyonlands National Park on the western rim of the Paradox Basin in southeastern Utah, USA (Fig. 2). This zone of extensive faulting is characterized by an arcuate array of grabens, also known as The Grabens, that extends over $20 \mathrm{~km}$ southward from the Colorado and Green River confluence and 5-6 km eastwards from the Colorado River. The grabens strike NNESSW in the northern section and gradually change to a more E-W orientation in the southern section (Fig. 3b; e.g., McGill and Stromquist, 1979). The most spectacular grabens are the northern ones, named (from east to west) Devil's Pocket, Devil's Lane, Cyclone Canyon, Red Lake Canyon, Twin Canyon and Lens Canyon. Grabens were proposed to become younger further to the east (Huntoon, 1982).

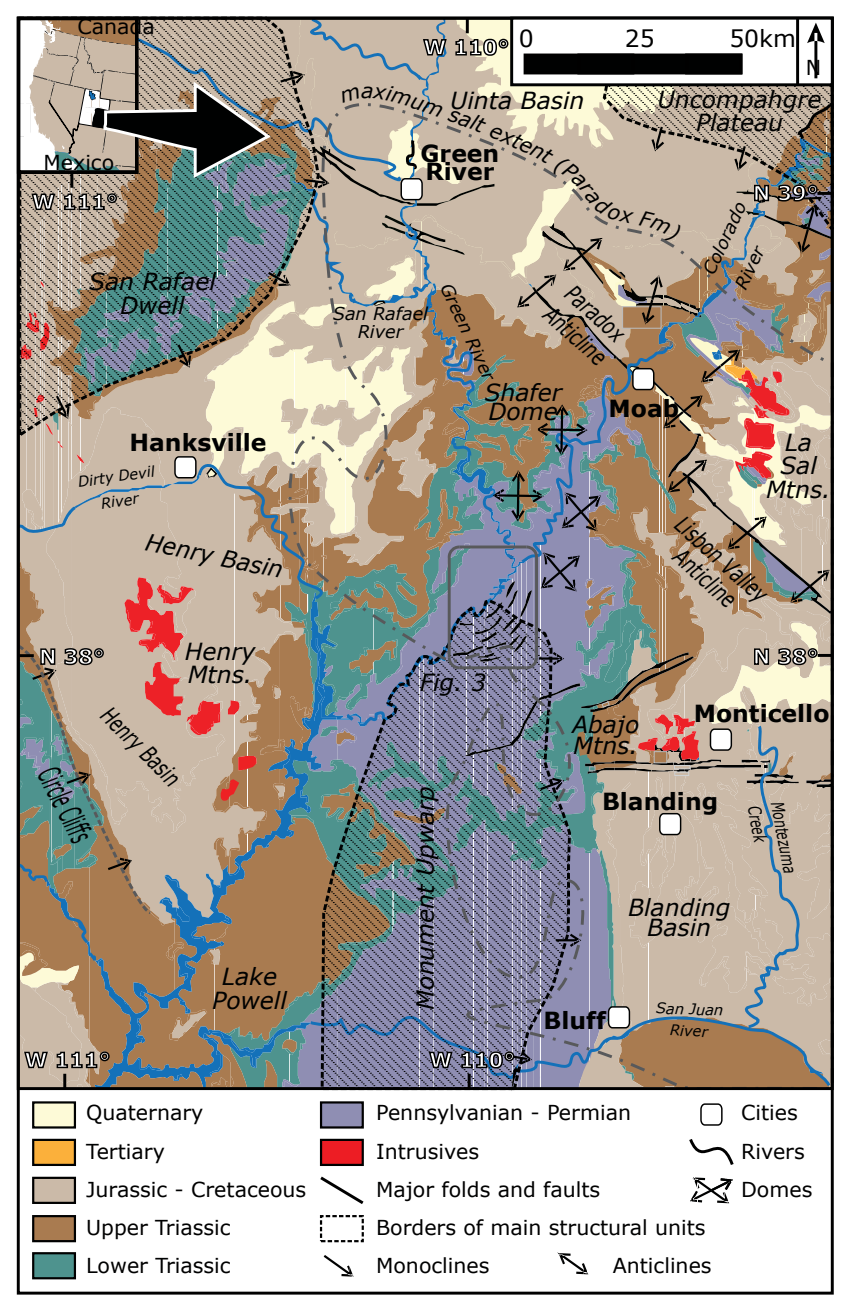

Figure 2. Geology of SE Utah and major structural units. Inlet indicates location of Fig. 3. The study area (grabens in the Canyonland National Park) is located at the northern end of the Monument Upward, east of the Colorado River. Geological and structural data compiled from Huntoon et al. (1982), Condon (1997), Hintze et al. (2000) and Gutiérrez (2004).

The regional tectonic influence of the Monument Upwarp (Fig. 2), a regional fold structure developed during the Laramide Orogeny in early Tertiary (Goldstrand, 1994; Condon, 1997; Walsh and Schultz-Ela, 2003), caused differential local tilting of the Needles fault zone, ranging from $2^{\circ}$ toward NW (Walsh and Schultz-Ela, 2003; Furuya et al., 2007) to $4^{\circ}$ toward WNW (McGill and Stromquist, 1979; Huntoon, 1982; Trudgill and Cartwright, 1994).

The stratigraphy of the study area consists of more than $300 \mathrm{~m}$ of Pennsylvanian evaporites at the base, mainly halite, gypsum and anhydrite (e.g., Cartwright et al., 1995). These units are now located at depths between 300 and $500 \mathrm{~m}$, and they crop out only within the Colorado River incision (e.g., Mertens, 2006). These are overlain by sandstones, intercalated shales and limestones of the Pennsylvanian, as well as 


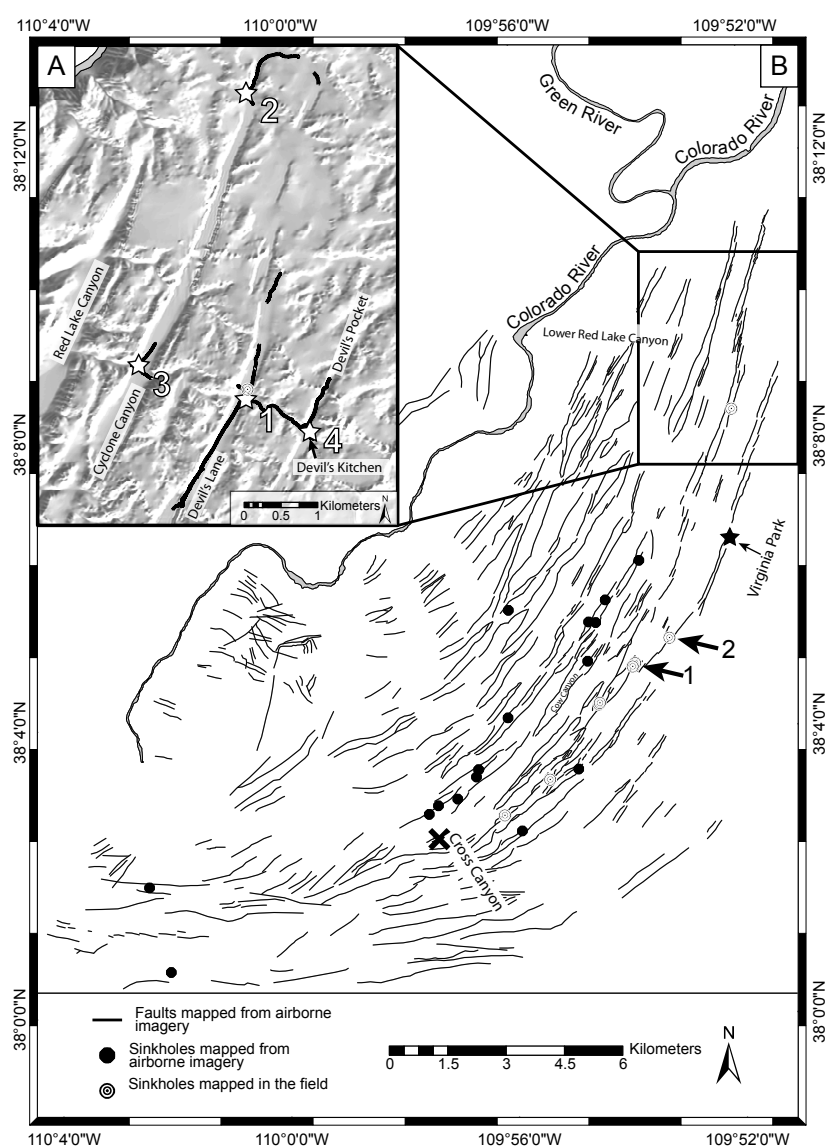

Figure 3. (a) Needles Area, northern part of the grabens as a hillshade digital elevation model (National Elevation Dataset, NED). Presented GRP profiles indicated by numbered stars. Entire collected GPR data set is shown by black lines. (b) Overview of the Canyonlands grabens. Graben-bounding faults mapped via orthoimagery. Sinkholes mapped in the field and from imagery.

the prominently jointed Permian Cedar Mesa sandstones on top (Lewis and Campbell, 1965; Huntoon, 1982; McGill et al., 2000). This entire overlying sediment package reaches up to $500 \mathrm{~m}$ in thickness (e.g., McGill and Stromquist, 1979; Trudgill and Cartwright, 1994; Schultz and Moore, 1996; Cartwright and Mansfield, 1998; Moore and Schultz, 1999; Fossen et al., 2010).

The grabens are filled with unconsolidated Quaternary soft sediments. According to the geological map of Billingsley et al. (2002) most of Devil's Pocket and Cyclone Canyon as well as northern Devil's Lane are dominated by Holocene and Pleistocene alluvial deposits. The southern section of Devil's Lane is mostly filled with Holocene alluvial fan deposits. Isolated depressions permitted ponding of Holocene silt and mud in Devil's Lane and Cyclone Canyon with sediment thicknesses of up to $2 \mathrm{~m}$. Faulting significantly influences the distribution of local deposition centers and the drainage system (Trudgill, 2002). All grabens contain rockfall debris (Fig. 1b).
Incision of the Colorado River, in combination with the local tilt, is seen by most researchers as the cause for the formation of the grabens, either due to salt movement or gravitational gliding. Huntoon (1982) proposed that salt movement occurs as a reaction to the unloading effect of the incising Colorado expressed as the Meander Anticline, a fold structure following the Colorado River, with the stream flowing in the fold axis striking roughly NNE. Furuya et al. (2007) showed by using InSAR measurements that the uplift of the Meander Anticline as well as the graben formation is ongoing, which is expressed most prominently by NW-oriented extensional movements of up to $3 \mathrm{~mm} \mathrm{a}^{-1}$ in the south of the grabens. Faulting in Canyonlands National Park occurs as aseismic creep; the only recorded earthquake activity was a series of microquakes in the spring of 1987, with magnitudes $M_{\mathrm{L}} \leq 1.8$ at a depth of $6-10 \mathrm{~km}$, which is far below the decoupling salt layer (Wong et al., 1993; Moore and Schultz, 1999).

To investigate sediment thicknesses and their distribution, Grosfils et al. (2003) and Abrahamson (2005) used seismic refraction surveys in northern Devil's Lane and Cyclone Canyon, respectively. Grosfils et al. (2003) additionally collected gravity data. They estimate maximum thicknesses of Pleistocene and Holocene sediments of more than $90 \mathrm{~m}$ in Devil's Lane and 60-75 $\mathrm{m}$ in Cyclone Canyon. The resulting total throw (i.e., sediment thickness plus graben wall height) in both grabens exceeds earlier estimates (e.g., Cartwright et al., 1995) by a factor of up to 1.5 (e.g., $\geq 145 \mathrm{~m}$ instead of $\leq 105 \mathrm{~m}$ for the master fault in Devil's Lane). In the following we distinguish between the terms graben-bounding fault, which is the actual fault plane and fault position forming the graben, and graben wall, which is the exposed rock on either side of the graben. The latter is almost invariably an original joint surface, in many cases affected by weathering.

In the northern section, the upper $100 \mathrm{~m}$ of outcropping hard rock are cut by two characteristic regular joint sets (e.g., McGill and Stromquist, 1979). One joint set strikes NNE, the second one SE. Both joint sets change their orientation slightly towards the south: the NNE set following the change of the graben orientation, while the second joint set stays roughly normal to the first one and to the faults with a deviation of up to $30^{\circ}$ in the vicinity of eastern Chesler Canyon. According to McGill and Stromquist (1979) these joint sets are older than the grabens. Their considerations are based on the variety of different angles between joint strike and graben wall orientation, which are consistent neither with shear nor an extensional origin of jointing. Additionally, the observation of joints with regular spacing at exposed graben floors (e.g., northern Devil's Lane) imply that they are older than the graben faults. Although joints can form at a high angle to normal faults due to the faulting (Destro, 1995; Kattenhorn et al., 2000; Balsamo et al., 2008), this does not apply to the grabens of Canyonlands National Park. Joints can be followed through the grabens over very long distances and crossing several faults that developed at different times. A 
formation of the joints due to faulting would cause the joints to develop differently at different faults, which is not the case here. Several authors claim that the faults were strongly influenced by the preexisting joints (McGill and Stromquist, 1979; Cartwright and Mansfield, 1998; McGill et al., 2000; Trudgill, 2002). The effect of joints on the geometry of fault tips has been described by Cartwright and Mansfield (1998), but an extensive analysis of the fault-joint relationship considering faults and joints in the entire grabens area and the related structures has not been done so far.

\section{Data sources and methodology}

Detailed mapping of faults and joints as well as a remotesensing analysis of topography and structures was carried out as a basis for geophysical data collection and field mapping. We used high-resolution airborne orthoimagery $(25 \mathrm{~cm}$ per pixel; Utah Automated Geographic Reference Center, 2009) for the northern section and aerial images with $1 \mathrm{~m}$ resolution (National Agriculture Imagery Program, 2009) for the southern parts. This imagery is also used in the figures of this paper. Maps throughout this paper, including the supplementary map, were created using ArcGIS ${ }^{\circledR}$ software by Esri. (ArcGIS $^{\circledR}$ and ArcMap ${ }^{\mathrm{TM}}$ are the intellectual property of Esri and are used herein under license. Copyright ${ }^{\circledR}$ Esri. All rights reserved.)

In addition to remote sensing and classical field mapping with GPS, compass, high-resolution photographs and a laser range finder, we used a ground-penetrating radar (GPR) system by GSSI (Salem, USA) to image subsurface features. The survey equipment consisted of the SIR 3000 field computer with GPS tracker, 100 and $400 \mathrm{MHz}$ antennas, and a survey wheel. We aimed at reaching penetration depths up to $10 \mathrm{~m}$ or more with the lower-frequency antenna. Data with a surface-near resolution better than $0.1 \mathrm{~m}$ are routinely gathered by the $400 \mathrm{MHz}$ system. Data processing was performed with the ReflexW software package (Sandmeier, 2011) and included static corrections, background removal, gain adjustments and frequency filtering. Topographic correction (Neal, 2004) was applied to those profiles with significant topographic variations only.

Wave travel times were converted into depths based on literature velocity values and hyperbola analyses where possible. Values between 0.1 and $0.15 \mathrm{~m} \mathrm{~ns}^{-1}$ were expected for the relatively dry sandy soils present in Canyonlands National Park (Smith and Jol, 1995; Heteren et al., 1998). Diffraction hyperbolae that were caused by single blocks in several profiles revealed velocities of $0.125 \pm 0.005 \mathrm{~m} \mathrm{~ns}^{-1}$. This value was used for the time-depth conversion in the profiles.

Vertical resolution of the data depends on the wave velocity as well. Maximum achievable vertical resolution is a quarter of the wavelength (wavelength equals wave velocity divided by frequency: $\lambda=v / f$; Neal, 2004) and thus approximately $0.08 \mathrm{~m}$ for the $400 \mathrm{MHz}$ antenna in our study.

A total of 66 GPR profiles were collected with a cumulative length of more than $7 \mathrm{~km}$, distributed over Devil's Pocket, Devil's Lane and Cyclone Canyon. The different antenna types were used to achieve either higher penetration depth or better resolution. Profiles normal to fault strike were investigated with both antennas as we expect them to show more structures than strike-parallel profiles. For minimum invasion on the sensitive biological soil crust (Rosentreter et al., 2007) we restricted our surveys to existing tracks and trails in agreement with the National Park Service.

\section{Remote sensing}

Modern airborne orthorectified photos with very high resolution (up to $25 \mathrm{~cm}$ per pixel) allow a detailed remote mapping of joints and faults in the Needles fault zone. To analyze orientations of the joint generations and the fault system, we mapped more than 20000 joints and 800 faults. Figure 4 shows all faults, divided into four sections with similar orientations. For each of the sections we plotted rose diagrams of fault and joint orientations, and for each section an airborne photograph is given with interpreted faults (white lines) and joints (red lines) as an illustration of our interpretations. Within each section the orientations are quite constant and one joint set is always parallel to the main faults. A detailed map showing joints and faults overlain on aerial photographs is included in the Supplement of this paper.

\section{Field observations}

We focused on Devil's Pocket, Devil's Lane and Cyclone Canyon sites because in these grabens the walls are less weathered and jointing is most distinct, but we also included an excursion to Cross Canyon in the south and Lens Canyon in the west. Besides the GPR data that are described later, we also collected basic geometric information of these grabens using a laser range finder and visual observations. Three major findings are of importance:

1. Along the four-wheel-drive track leading from Devil's Lane southwards along the Bobby Jo Camp to Bobby's Hole we observed a number of localized depressions at graben boundaries and faults, interpreted as sinkholes in agreement with work by Biggar and Adams (1987). The sinkholes can span from a few meters to tens of meters in length and several meters in depth. Numerous sinkholes observed in airborne imagery are not located at graben boundaries but coincide with faults within or across grabens. Figure 5a shows an example of an airborne image of such a sinkhole located at the eastern graben wall in a graben east of Cow Canyon (see arrow "1" in Fig. 3). A channel-like structure protrud- 


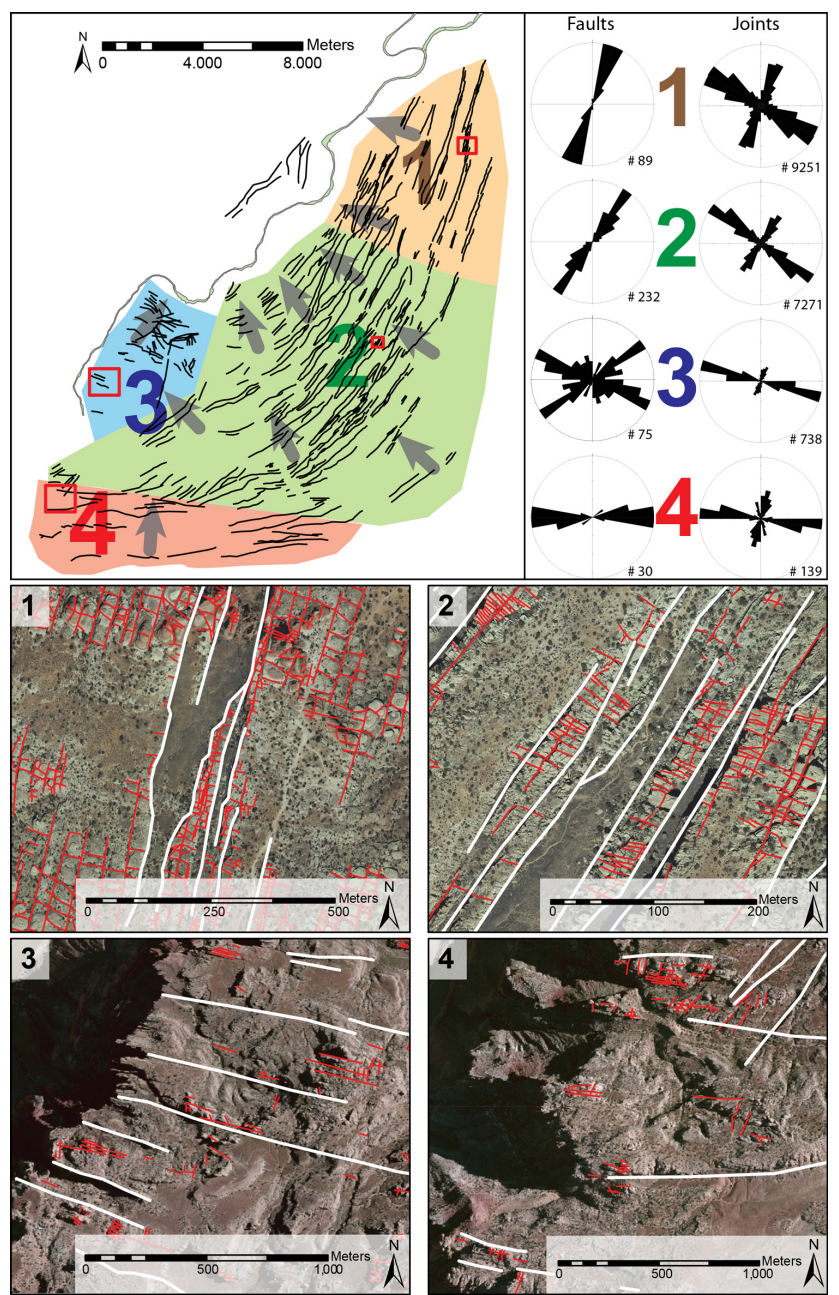

Figure 4. Fault and joint orientations in the Needles fault zone derived from airborne image mapping. Four sections group areas of similar orientations. One joint set is always parallel to the major faults. Small red rectangles depict locations of associated detail photographs showing the interpretations of faults (white lines) and joints (red lines). Numbers $1-4$ on the photographs correspond to the sections. Gray arrows indicate the local direction of graben opening.

ing towards the graben wall indicates sediment transport towards the depression at the graben wall. The corresponding field photograph (Fig. 5b) shows the geometry and extent of this sinkhole. Apparently, water as well as transported sediment disappears underground at these locations. Due to their depth of several meters they often act as a trap for the abundant tumbleweed. It is unclear, however, whether there is an interconnected system of open fractures that allows a transport of sediments over larger distances, or whether the opening rate of these fissures is larger than sediment input, such that they do not fill up. Figure $5 \mathrm{c}$ shows a sinkhole that is not located at a graben boundary but at a graben-crossing fault (for lo- cation see arrow "2" in Fig. 3). The corresponding field photograph (d) shows the dimension of the sinkhole and the void where rainwater and sediments are transported underground. According to national park staff, this sinkhole opened up in 2011 during heavy rainfall, which washed away the sediment cover.

2. At three locations we were able to exactly measure heave and throw of offset blocks that remained visible within the grabens. While throw can be determined precisely by horizontal marker beds, heave is affected by an unknown amount of erosion, and thus measured values are considered overestimates. One measurement was done in northern Devil's Pocket (Fig. 6a). The throw at the western graben wall could be measured quite precisely $(38.7 \mathrm{~m})$ using the laser range finder. The heave is estimated to be $\sim 20 \mathrm{~m}$, but rockfall from the graben wall has likely affected the heave here. In Devil's Pocket south of Devil's Kitchen a huge offset block is located within the graben (Fig. 6b), and marker horizons allowed measuring a throw of $31 \mathrm{~m}$ and a heave of $8 \mathrm{~m}$. Again the heave is affected by erosion and is therefore slightly overestimated. A second block further west is relatively higher than the previous, implying a second fault in between. A third outcrop is located right at the previously described sinkhole east of Cow Canyon (cross in Fig. 3) and depicted in Fig. 6c. The throw is $2.4 \mathrm{~m}$ and the heave $7.8 \mathrm{~m}$. Note that the heave is more than 2 times larger than the throw, indicating a very shallow dipping fault.

3. To test hypotheses on dilatant faulting, we looked for slickensides or tool marks at non-weathered fault/joint surfaces. Moore and Schultz (1999) described slickenlines at calcite-coated joint surfaces, but we did not find any examples of that. Calcite coatings on joint surfaces that subsequently accumulate displacement due to underlying faulting are formed by rainwater flow over the surfaces in streams, thus producing irregular trails of calcite. Further it is possible to form tool marks on soft calcite coatings by reworking of rockfall debris even in extensional faulting regimes. The majority of our observations point to extensional fracturing, without frictional sliding (Fig. 7).

\section{GPR observations}

A number of profiles selected for their descriptive value are shown and interpreted in the following paragraphs. Especially the profiles crossing from a graben to a horst, thus being crosscuts of a graben-bounding fault, show the most interesting results. The given examples illustrate sediments dipping towards the graben wall, sediments dipping towards the graben center, changing deposition rates within a graben 

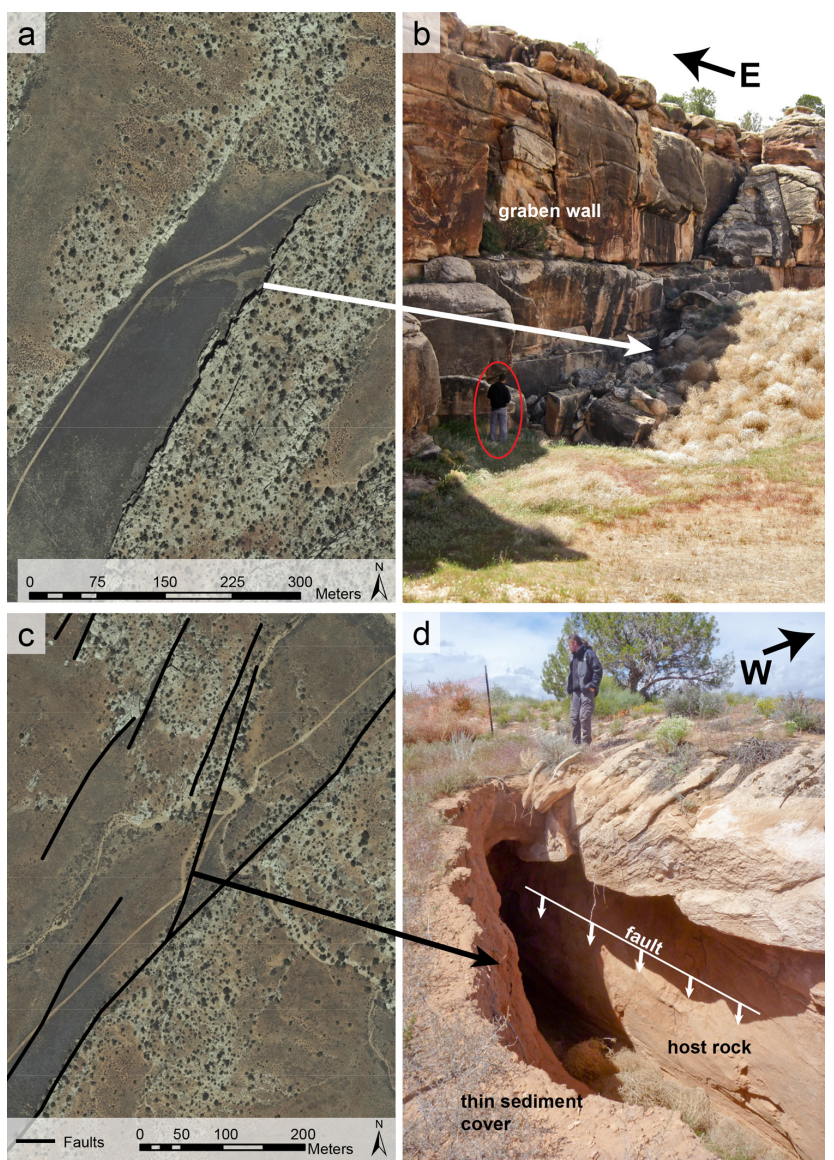

Figure 5. (a) Aerial photograph showing the location and surface depression of a large sinkhole (cf. arrow "1" in Fig. 3). (b) Field photograph showing the same sinkhole (person in the ellipse for scale). Material is lost into a cavity or an interconnected system of open fractures allowing an outflow of sediments in the subsurface. (c) Airborne photograph showing location of another sinkhole not located at a graben wall (cf. arrow " 2 " in Fig. 3) but at a grabencrossing fault. (d) Corresponding field photograph illustrating open gap at fault.

and graben-internal faulting. Dip angles of the faults cannot be determined exactly since depth migration of the GPR data was not possible due to amplification of artifacts during migration. The location of all described profiles is illustrated in Fig. 3a with numbers according to the subheadings.

\subsection{Devil's Lane WE profile}

The profiles were acquired with both the 400 and $100 \mathrm{MHz}$ antenna and stitched from two segments each (see white suture lines). They cross Devil's Lane from the western graben wall over $135 \mathrm{~m}$ to ESE as illustrated in Fig. 8. Radargrams and interpretations are depicted in Fig. 9 and Fig. 10 for the $400 \mathrm{MHz}$ profile and the $100 \mathrm{MHz}$ profile, respectively.

Both antennas image sediments dipping towards the graben-bounding fault in the form of growth strata over a
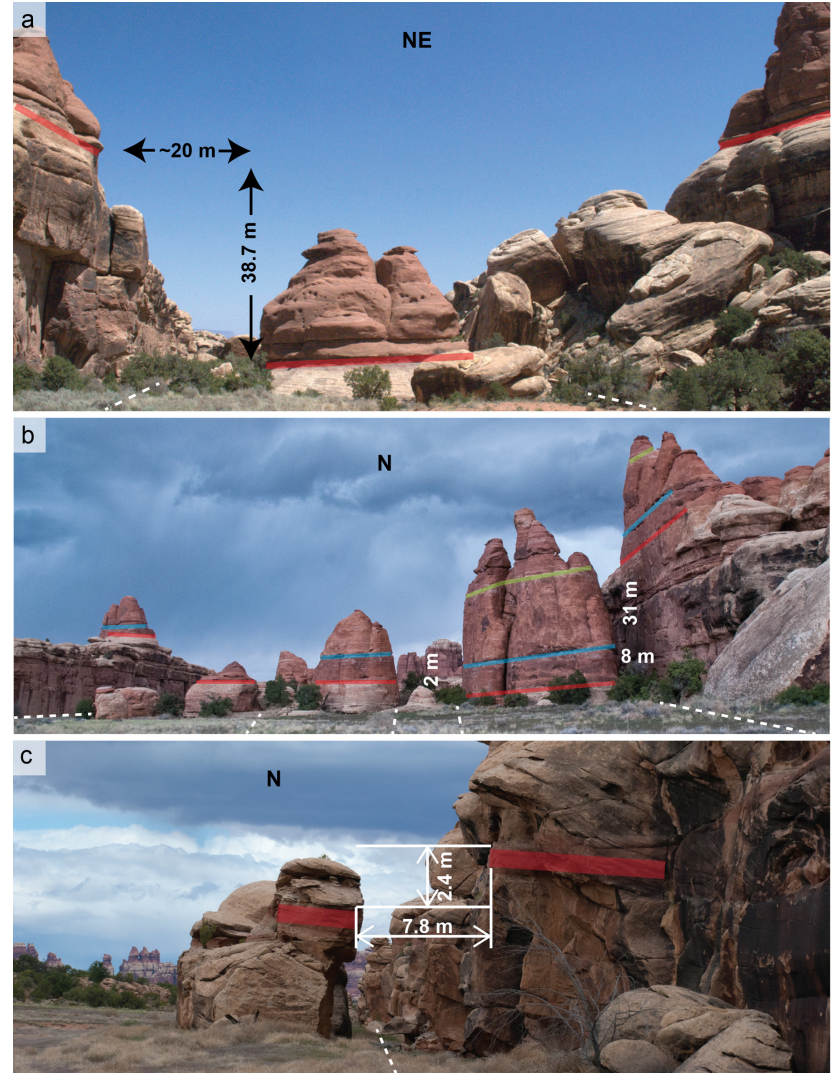

Figure 6. Three locations where heave and throw were measured and fault dips at depth were estimated. (a) Northern Devil's Pocket. (b) Southern Devil's Pocket. (c) Unnamed graben east of Cow Canyon. Individual heave and throw values are given in images. Dashed lines indicate estimated position of faults.

length of 30-40 m, but they differ in the depth at which they can be observed. Whereas layers may be interpreted to become horizontal at a depth of around $2.5 \mathrm{~m}$ in the $400 \mathrm{MHz}$ profile, the $100 \mathrm{MHz}$ antenna shows dipping structures down to $5 \mathrm{~m}$ depth. The discrepancy is assumed to be the result of different resolutions. In the airborne imagery (a) this area coincides with darker colors, indicating more humidity and a slight surface depression, which is also observable in the field.

More localized areas of dipping strata are observed in three other positions. Dips from the west towards the $60 \mathrm{~m}$ mark can be observed in the $400 \mathrm{MHz}$ profile as well as dips from the east towards the $60 \mathrm{~m}$ mark, at depths of up to approximately $1.5 \mathrm{~m}$. These are not visible in the $100 \mathrm{MHz}$ profile, although here some dipping occurs from $60 \mathrm{~m}$ westwards at depths between 2 and $5 \mathrm{~m}$. Some west-dipping layers in the upper meter are found in the $400 \mathrm{MHz}$ profile between 85 and $90 \mathrm{~m}$ but not at all using $100 \mathrm{MHz}$. Finally, some eastdipping strata occur east of $115 \mathrm{~m}(400 \mathrm{MHz})$ down to $1 \mathrm{~m}$ and east of $125 \mathrm{~m}(100 \mathrm{MHz})$ between 2 and $3.5 \mathrm{~m}$ depth. In general, both antennas show very similar features at the same 

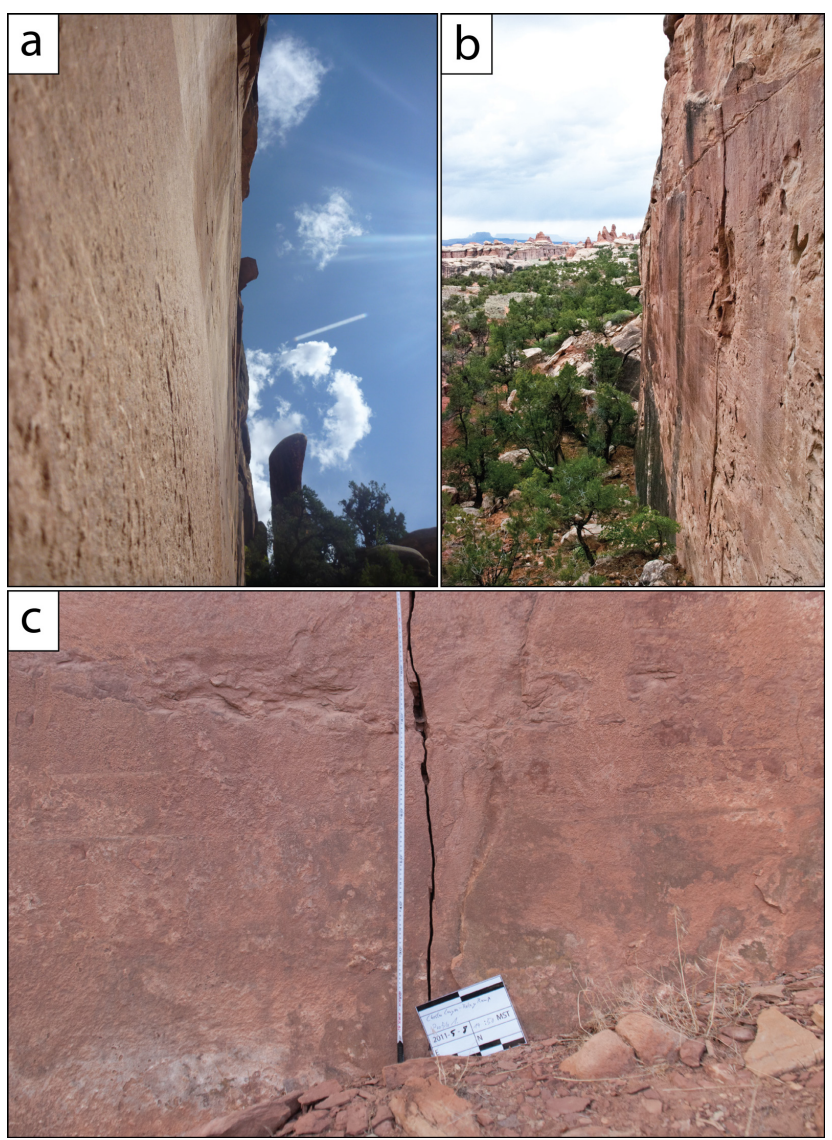

Figure 7. Widely unweathered surfaces of joints that accommodated offset due to underlying faulting show no slickenlines or tool marks at (a) northern Devil's Pocket, (b) southern end of Devil's Pocket and (c) Devil's Lane relay.

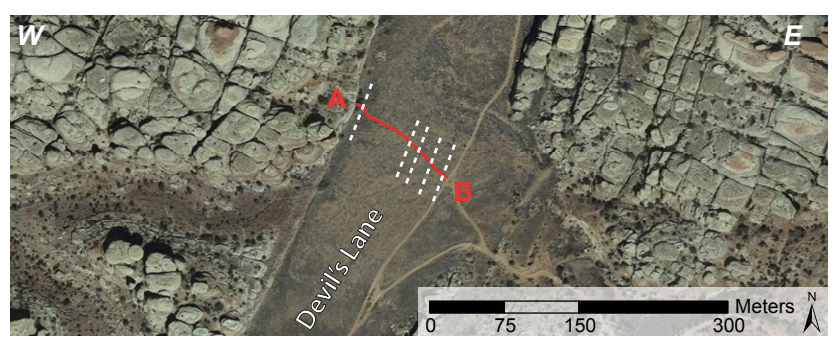

Figure 8. Aerial photograph of the WNW-ESE (red line) profiles crossing through Devil's Lane. (a) Interpreted faults are indicated by white dashed lines.

positions, although they differ in the depths at which the observations can be made.

In addition to dipping sediments we interpret a number of faults in these profiles (Figs. 9b and 10b) which cannot be seen at the surface. These faults mostly correlate between both profiles, although some smaller faults seen in the $400 \mathrm{MHz}$ profile could not be resolved in the $100 \mathrm{MHz}$ profile. The average spacing between the faults is about 10 to

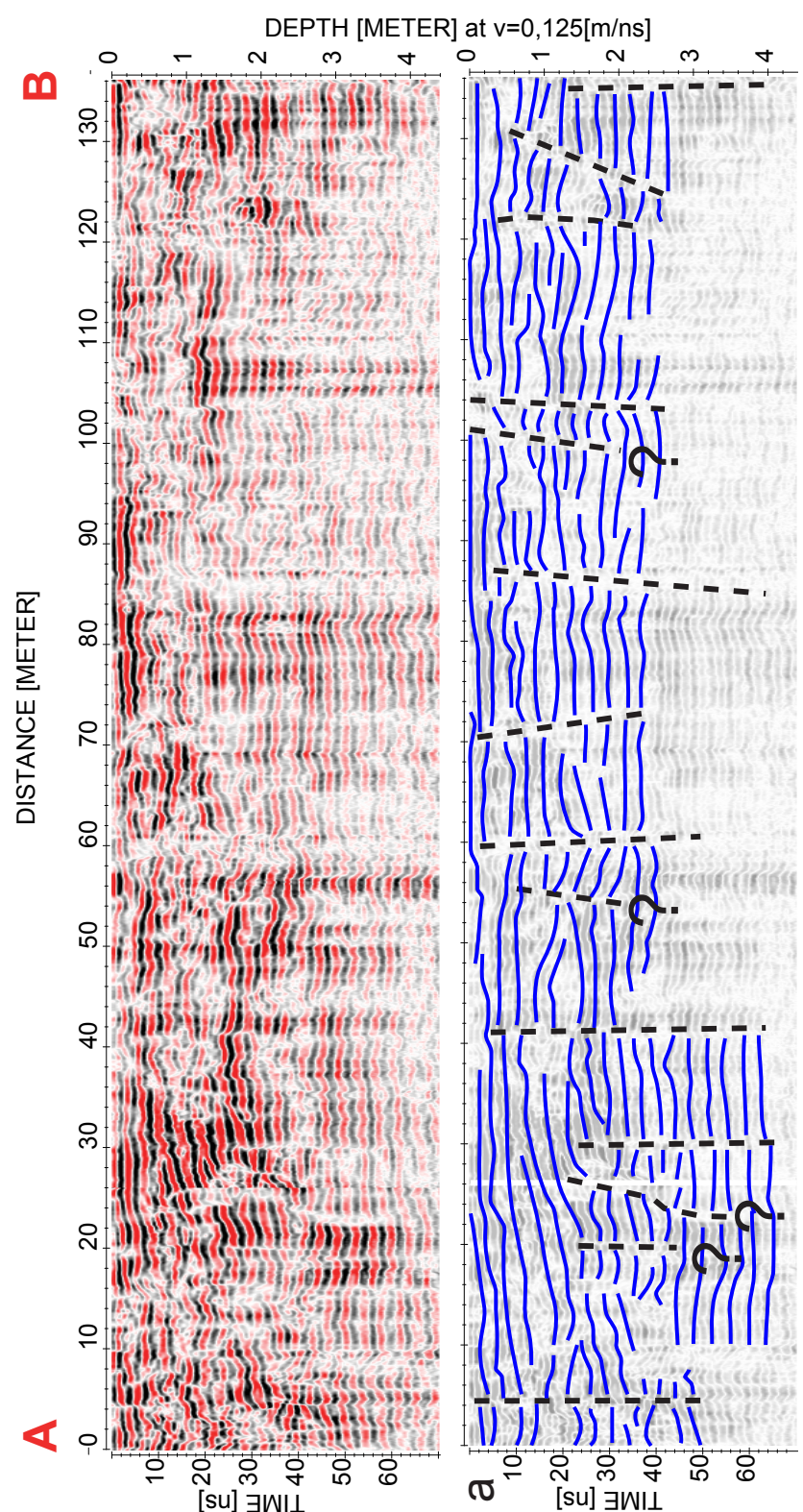

Figure 9. Radargram (a) and interpretation (b) of the WNW-ESE (red line) profile crossing through Devil's Lane of the $400 \mathrm{MHz}$ antenna. Blue lines show interpreted reflectors; dashed lines represent interpreted faults. A number of faults appear in the profile, some of which do not reach the surface.

$15 \mathrm{~m}$. Many faults reach up close to the surface, but there are also some that show no more offset at depths of several meters.

\subsection{Northern Cyclone Canyon WE profile}

This $100 \mathrm{MHz}$ profile in northern Cyclone Canyon starts at the western graben wall and follows the trail to the SE (see Fig. 11a). It shows a sediment package of about $10 \mathrm{~m}$ thickness dipping from the surface down to $10-20 \mathrm{~m}$ depth over 

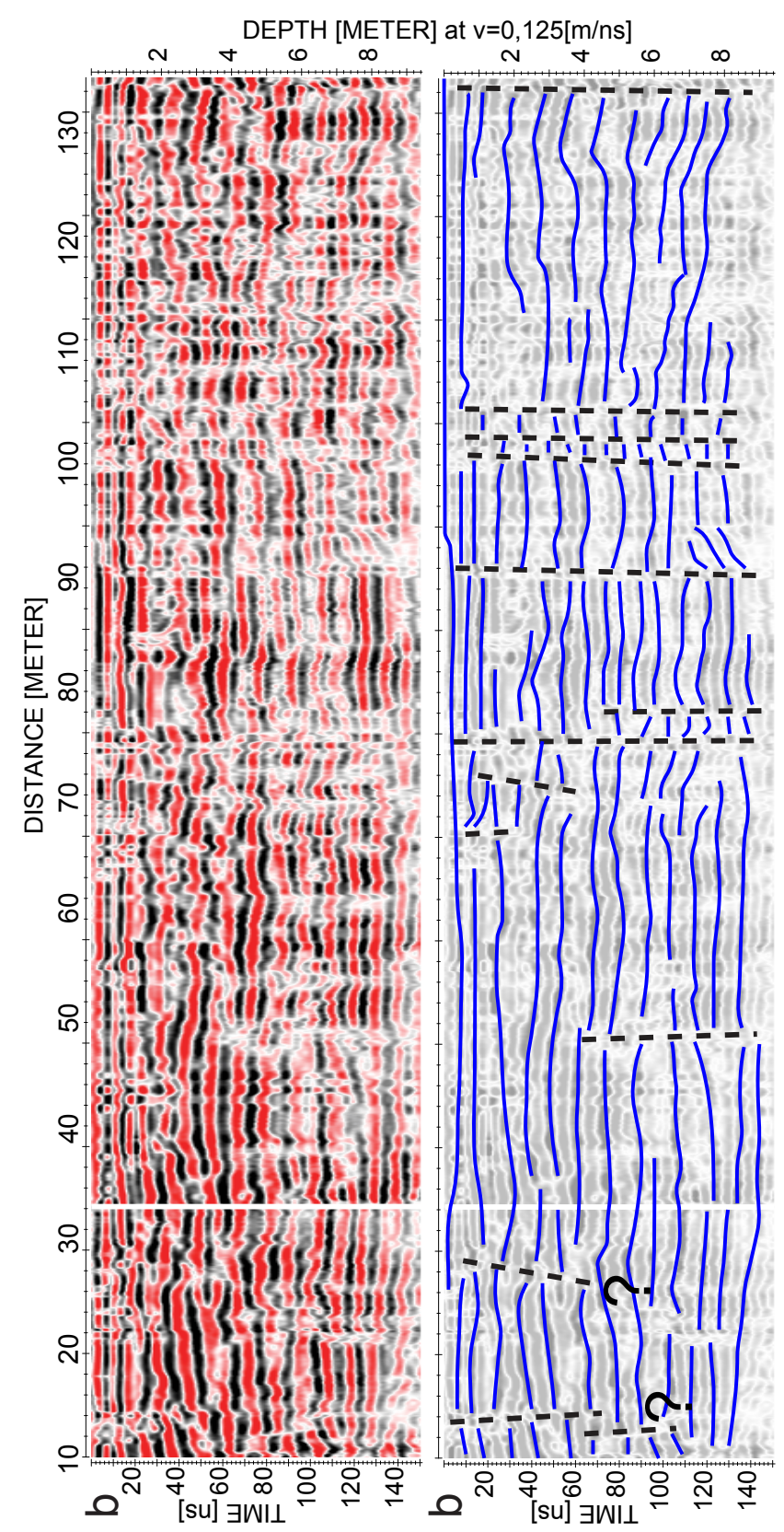

Figure 10. Radargram (a) and interpretation (b) of the WNW-ESE (red line) profile crossing through Devil's Lane of the $100 \mathrm{MHz}$ antenna. Blue lines show interpreted reflectors; dashed lines represent interpreted faults. In general the profile is similar to the $400 \mathrm{MHz}$ profile. The locations of major faults coincide.

a length of $100 \mathrm{~m}$ along the profile. This dip is only an apparent dip, as the actual structure is unknown (e.g., alluvial fan). The overlying horizontal layers gain thickness along the profile and finally reach down to $10 \mathrm{~m}$.

In this profile there are also faults to be found as illustrated by dashed lines and named in Fig. 12b. We interpret three major faults and four associated minor faults. Fault 1 is clearly visible due to terminating reflectors and a change in
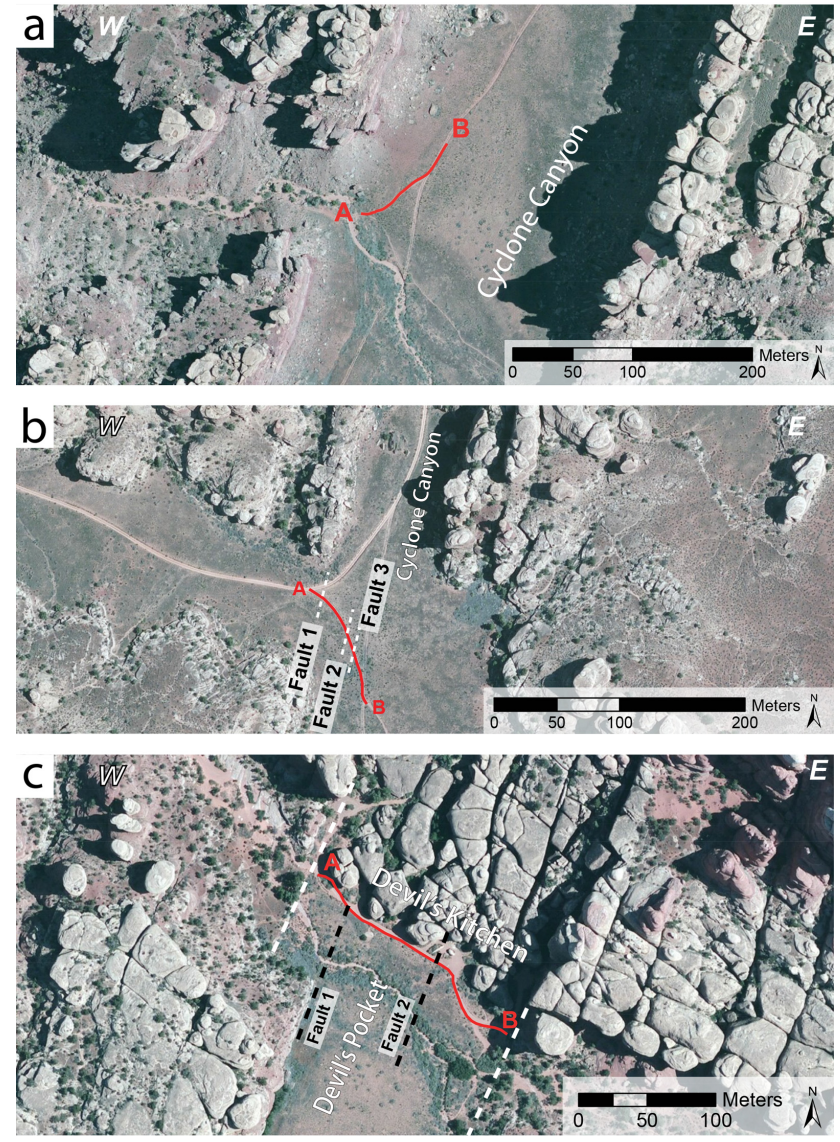

Figure 11. Photo plate showing the traces of GPR profiles in (a) northern Cyclone Canyon, (b) central Cyclone Canyon and (c) Devil's Kitchen.

reflector intensity at the $16 \mathrm{~m}$ mark. This fault is interpreted to be the graben-bounding fault of the northern graben segment. Faults 2 and 3 are located more distal from the graben wall and both show small associated faults to their west. Again, terminating reflectors and changes in reflector intensity indicate the existence of these faults. The strike direction of faults 2 and 3 is uncertain, but we assume them to be parallel to fault 1 , following the general regional trend of fault strikes. The three major faults are indicated as interpreted with white dashed lines in the airborne image (Fig. 11a).

\subsection{Central Cyclone Canyon WE profile}

Evidence for changes in either deposition or deformation rate were found in a profile in central Cyclone Canyon, starting at the western graben wall and then changing to a NNE direction as illustrated in Fig. 11b. This $85 \mathrm{~m}$ long profile was shot using the $400 \mathrm{MHz}$ antenna to achieve a high resolution in the upper $4 \mathrm{~m}$ of sediments. Figure 13a shows the profile without interpretation, and Fig. 13b indicates the prominent sedimentary features as we interpret them. Three distinct horizontal beds can be seen here - the first one being within the 


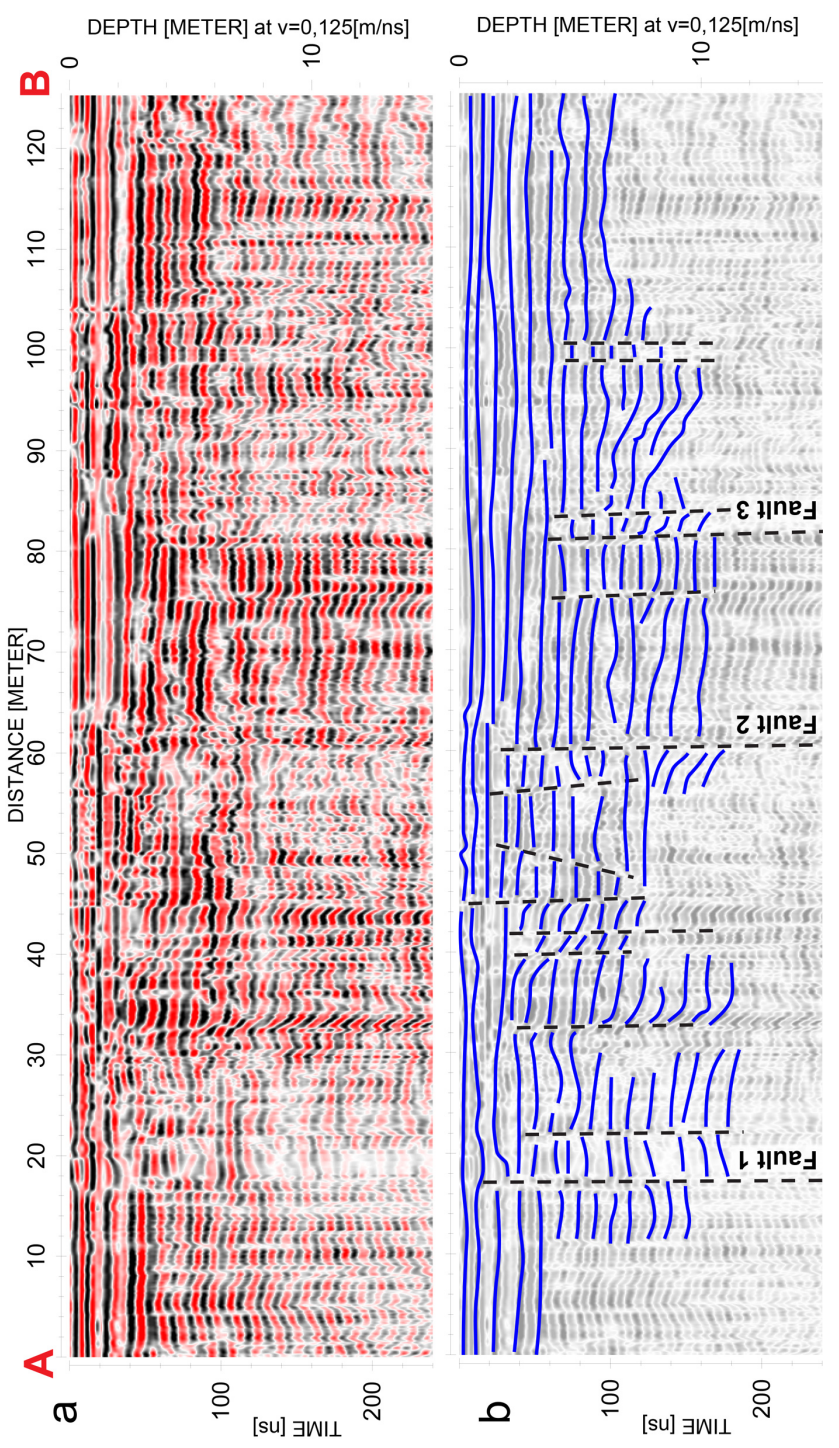

Figure 12. NW-SE profile in northern Cyclone Canyon. (a) $100 \mathrm{MHz}$ profile without interpretation. (b) Profile with interpretation (blue lines: interpreted layers; dashed lines: interpreted faults). Faults 1-3 are also shown in Fig. 11a.

upper $0.2-0.4 \mathrm{~cm}$, the second one at a depth of about $2.2 \mathrm{~m}$ and the third one at about $3.4 \mathrm{~m}$ depth.

The distance between the two deeper horizons is about $1.2 \mathrm{~m}$, and they are separated by material producing diffuse and wavy reflectors. The vertical distance between the two upper horizons is about $2 \mathrm{~m}$, and the sediments in between show several cycles of foreset beds and onlaps, typical in deltaic sequences. Apparent dips along the profile are to the E/NNE, although the last $25 \mathrm{~m}$ of the profile also reveal layers with different dips, onlapping on the NNE-dipping sediments. No clear sign of faulting was observed here.

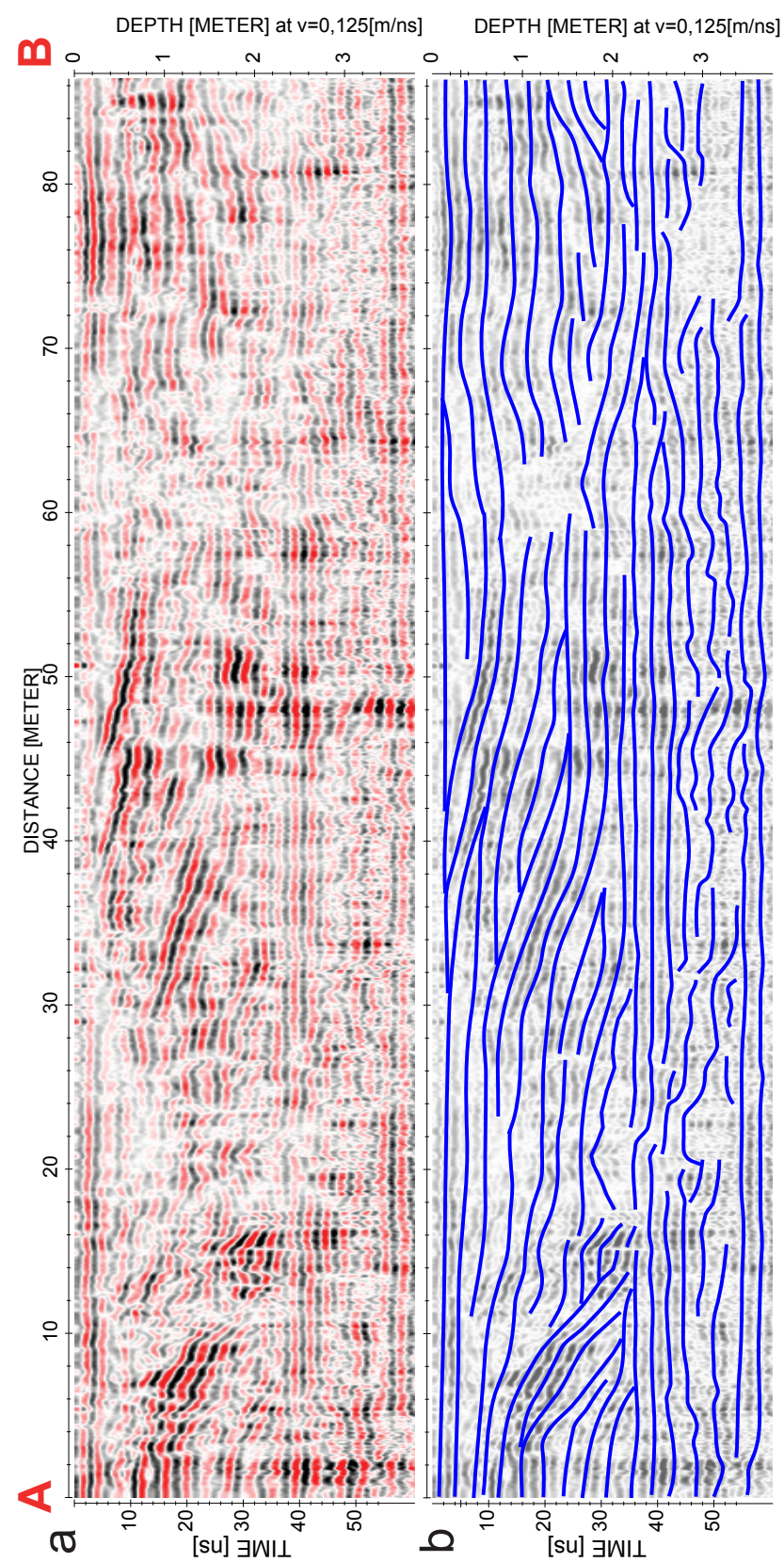

Figure 13. SW-NE profile crossing the central Cyclone Canyon. (a) $400 \mathrm{MHz}$ profile without interpretation. (b) Profile with interpretation (blue lines: interpreted layers). This profile shows no faults but sedimentary structures such as foreset beds.

\subsection{Devil's Kitchen WE profile}

This $400 \mathrm{MHz}$ profile was taken along a WNW-ESE path crossing Devil's Kitchen as shown in Fig. 11c. It starts right behind the western graben-bounding fault of the northern section of Devil's Pocket graben and then leads to the eastern graben wall, again not crossing the bounding fault. Both bounding faults are indicated by white dashed lines in Fig. 11c. Due to the high resolution, the profile provides use- 


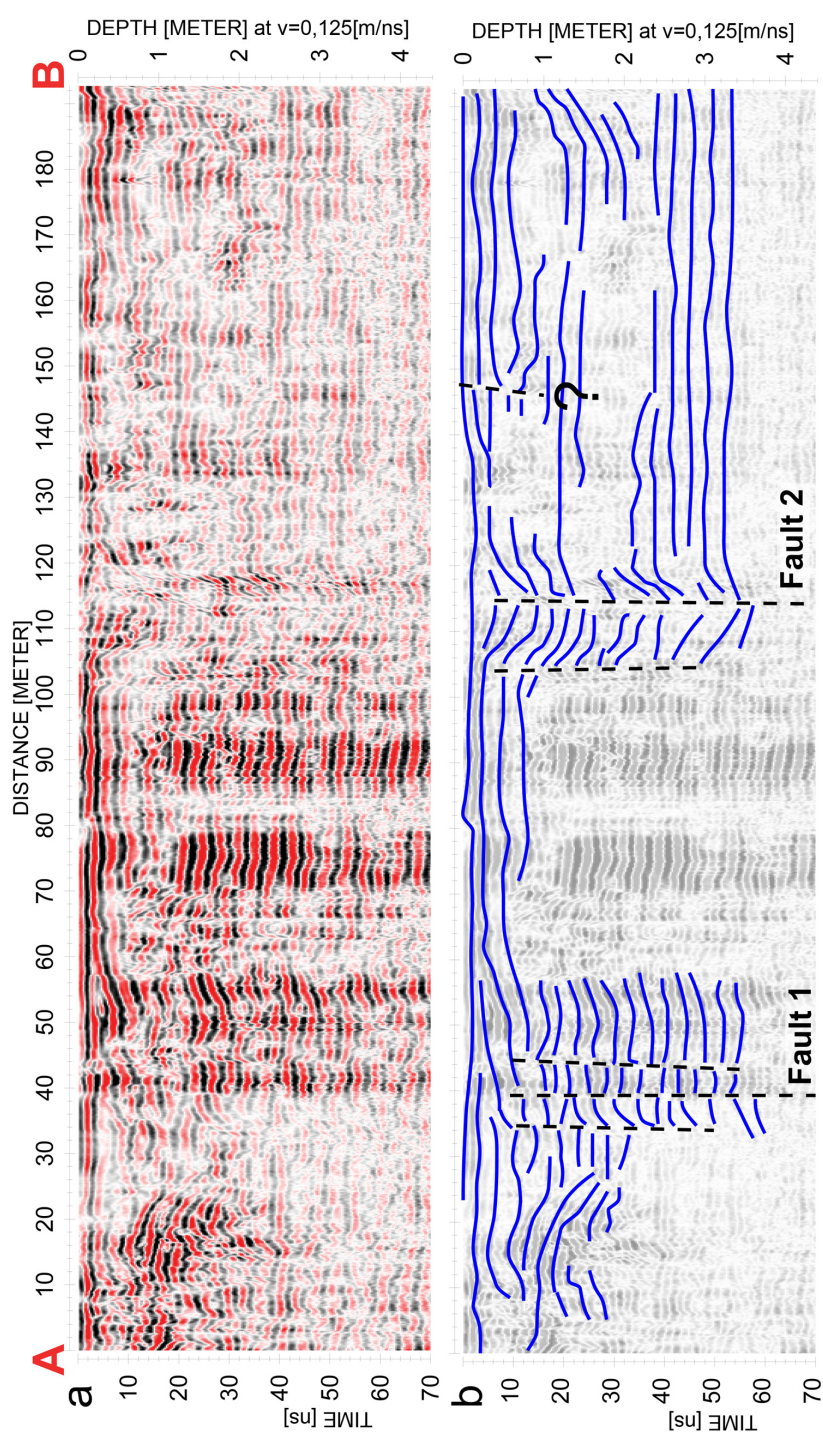

Figure 14. Devil's Kitchen WNW-ESE profile. (a) $400 \mathrm{MHz}$ profile without interpretation. (b) Profile with interpretation (blue lines: interpreted layers; dashed line: interpreted faults). Faults 1 and 2 are also outlined in Fig. 11c.

ful information only down to 5-6m. Figure 14 a depicts the raw profile after processing, while in Fig. 14b we present our interpretation. Two major faults are visible by terminating reflectors and changing reflector intensity. Fault 1 is located at around $40 \mathrm{~m}$ and shows at least three fault strands as illustrated by dashed lines in Fig. 14b. Caused by the lack of GPR information, the lower extent of the fault cannot be determined. Nevertheless, all fault strands appear to have their upper fault tip at a depth of about $0.5 \mathrm{~m}$. Fault 2 (at $115 \mathrm{~m}$ ) is less sharply defined and characterized by reflectors dipping diffusely towards the interpreted slip plane. Its upper termination is again assumed to be at a depth of $0.5 \mathrm{~m}$. The assumed fault traces for both faults are also marked in the airborne photograph (Fig. 11c) by black dashed lines.
Sedimentary structures vary strongly throughout the profile. The westernmost section has sediments dipping towards fault 1 at a depth of $0.5-2 \mathrm{~m}$, while in the uppermost $0.5 \mathrm{~m}$ west-dipping layers overlie the faulted segment. These westdipping layers extend to a depth of about $3 \mathrm{~m}$ on the eastern side of fault 1 and show lateral extents from 0.2 to $0.3 \mathrm{~m}$. Layers in the upper $0.3-0.4 \mathrm{~m}$ of the entire profile are horizontal. Sediments at fault 2 dip towards it from both sides but in a rather small lateral extent of about 5-10 m each. At the easternmost section of the profile, layers dip to the west at depths of $1-2.5 \mathrm{~m}$ and a lateral extent of roughly $25 \mathrm{~m}$. Parts not affected by the described dipping layers are characterized by horizontal reflectors through the entire sediment layer down to $5 \mathrm{~m}$.

\section{Interpretation and discussion}

Combined with the field and remote-sensing data (observations, mapping, airborne imagery and digital elevation models), the information derived from the GPR profiles supports and enhances the knowledge of how the grabens form and which processes are involved.

\subsection{Evidence for dilatant faulting}

The key evidence for dilatant faulting is the occurrence of sinkholes that we observed along graben-bounding faults in the more eastern grabens (cf. Fig. 3). Tensile opening gaps allow water and sediments to be transported underground (Fig. 5). Analysis of airborne imagery showed several sinkholes located within grabens at locations where a fault is crossing. These sinkholes are comparable to pit craters described by Ferrill et al. $(2004,2011)$.

Also, during our fieldwork we never observed slickensides at surfaces of unweathered joints that accommodate offset and extension due to reactivation by underlying normal faults. Slickenlines should be abundant at discrete slip surfaces in an area with as many faults as the Needles fault zone. The absence of such striations indicates dilatant faulting by reactivation of the preexisting vertical joints.

Layers distinctly dipping towards the graben wall, partly in the form of growth strata, require a depression into which they can dip. The GPR profile from Devil's Lane (Fig. 9) shows an example of this. At both ends of the profile, layers dip towards the respective graben wall with growth strata at the western graben wall. The profile from Devil's Pocket (Fig. 14) partially shows this situation. Layers to the east of fault 1 dip towards the western graben wall, and at fault 2 dip occurs from east and west.

\subsection{Fault shape}

The combination of opening of preexisting joints during faulting and the considerable vertical displacement in the grabens requires the presence of non-vertical faults at depth. 


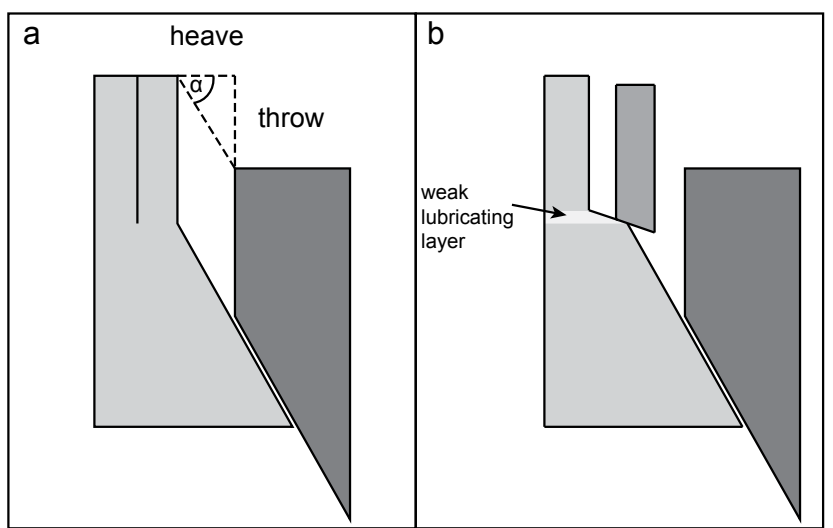

Figure 15. (a) Geometric relation between heave, throw and fault dip. (b) Lubricating layer can cause large blocks to break down.

The measurements of heave and throw in Devil's Pocket, Devil's Lane and the graben east of Cow Canyon provide direct evidence of fault dip at depth according to geometric considerations illustrated in Fig. 15a. The fault dip $\alpha$ is defined as $\alpha=\arctan$ (throw/heave). Joint surfaces that were once connected are now separated by several meters horizontally while also showing distinct vertical offset. Estimates of this are highly variable and show required fault dips of $60-80^{\circ}$ at depth in Devil's Pocket to produce the observed offsets, whereas in other cases very shallow dipping extensional faults are assumed. Disregarding the erosional effect on the heave, in the graben east of Cow Canyon a fault dip of less than $20^{\circ}$ is calculated. This can be explained by a secondary low-angle slip on a lubricating layer due to removing the confinement in the initial tensile deformation (see Fig. 15b). However, erosion at the fracture surfaces may lead to overestimation of the heave and result in underestimation of fault dips. For a detailed correction of erosion the exact timing of fracture opening and erosion rates over time would be needed, which is beyond the scope of this work. An underestimation of fault dips does not have an effect on the proposed model.

Other authors have found field evidence for such a vertical change of the fault dips in the grabens of the Canyonlands by investigating crosscut grabens along Y Canyon, Cross Canyon and Lower Red Lake Canyon. Based on observations in these crosscuts McGill and Stromquist (1979) proposed that faults are vertical over about $100 \mathrm{~m}$ followed by dips of about $75^{\circ}$ down to the evaporite interface. This observation was confirmed by Moore and Schultz (1999) by investigations in the same area.

A similar fault geometry is reproduced in the experiments of Holland et al. (2006) and van Gent et al. (2010). They used hemihydrate powder to investigate the evolution of normal faults in brittle materials and observed a tensile fracturing in the upper fault sections, a mixed-mode fracture in the middle and a shallow dipping shear movement in the lowest part of the fault zone. Hence, the surface expression of these faults is a vertical cliff with an open void at the graben-bounding fault and some vertical offset. Kettermann and Urai (2015) studied the lateral geometry of brittle faults in analogue models using hemihydrate powder. They described a rough and patchy geometry with relays and large blocks rotating into the fault as a result of linkage of fault segments. Similar features are described in basalts of Hawaii by Holland et al. (2006).

This 'pull-apart' model in mechanically layered stratigraphy causing opening in the more competent layers is well known from outcrops (e.g., Peacock and Sanderson, 1992; Peacock, 2002; Ferrill and Morris, 2003; Crider and Peacock, 2004; Ferrill et al., 2014) and shown in DEMs as well (e.g., Schöpfer et al., 2007a, b, c; Abe et al., 2011). We suggest that in the Canyonlands this effect is additionally controlled by the abundant vertical joint sets that are defining the presentday graben walls.

Analogue modeling of the interaction of preexisting joints and normal faults in brittle rocks was performed by Kettermann (2012). The basic deformation box, setup and scaling relations were the same as in the work of Holland et al. (2011). Additionally, joints were introduced to the system by hanging sheets of paper into the box during filling and carefully removing them before the deformation. As the hemihydrate is cohesive, open joints are formed and can then affect the faulting. The maximum depth of the joints as well as the joint spacing was chosen to represent the situation in the Canyonlands. In a series of experiments the angle between joint strike and fault strike was varied in a range observed in the field. Figure 16 shows a top view of an experiment with an $8^{\circ}$ angle between joint strike and basementfault strike. Observed structures are very comparable to the Canyonlands in that open fractures form close to the surface and original joint surfaces are preserved.

A fault-joint relationship was similarly observed in volcanic structures in Iceland (Gudmundsson and Bäckström, 1991; Angelier et al., 1997). Although several times larger than the Canyonlands grabens, the Sveinagja graben in basalts of northeast Iceland (Gudmundsson and Bäckström, 1991) resembles a similar situation. A $34 \mathrm{~km}$ long graben structure shows large open gaps along the bounding faults. Heave and throw values indicate comparable fault dips of about $60^{\circ}$ at depth, while close to the surface the faults localize along preexisting cooling joints in columnar basalts. Angelier et al. (1997) studied the Krafla fissure swarm in northeastern Iceland, which also consists of extensional fractures and faults in middle-ocean ridge basalts. They concluded average fault dips at a depth of about $70^{\circ}$ and a vertical upper section, controlled by cooling joints, thus being comparable to the Canyonlands situation.

It is, however, possible that joints subparallel to a basement fault form as initial stage of deformation (e.g., Destro, 1995; Kattenhorn et al., 2000; Balsamo et al., 2008). Later the main faults from underneath can localize along these early formed joints and accommodate offset as observed by 


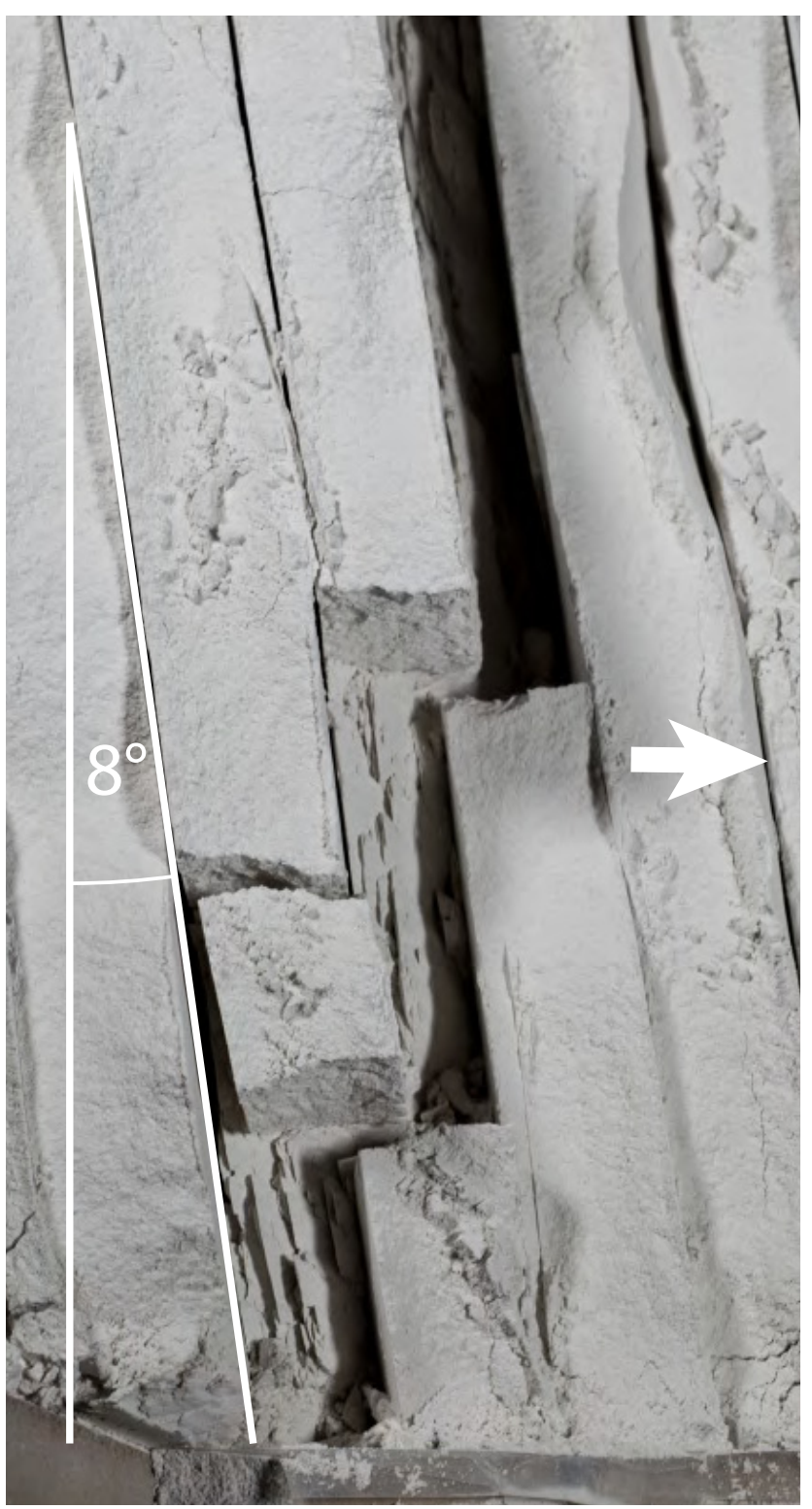

Figure 16. Top view image showing an analogue experiment of Kettermann (2012) with $8^{\circ}$ fault-joint angle after deformation. Main fault localized at preexisting joints exclusively; open gaps formed where the shallower dipping fault cuts the vertical joints. Original joint surfaces are preserved.

Grant and Kattenhorn (2004). These joint-related faults can look quite similar to the faults described in this paper; however the joints are always slightly inclined towards the faults.

In general, as both faults with and without preexisting vertical joints can form vertical extension fractures at low overburden stresses, the main difference is the lateral geometry. Without preexisting joints the heterogeneity of the rocks defines the position of individual fault segments in an early stage that link (hard link or soft link) with increasing displacement and finally form typical faults with relays and fault

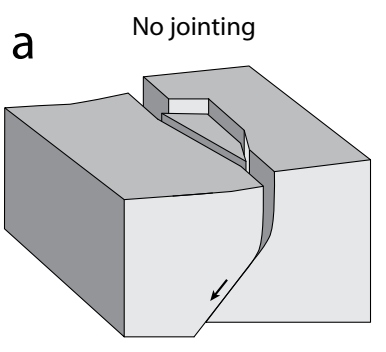

after van Gent et al. (2010), Holland (2010), Kettermann et al. (2015)

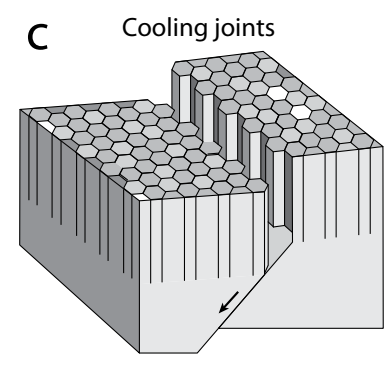

after e.g. Gudmundsson (1992)

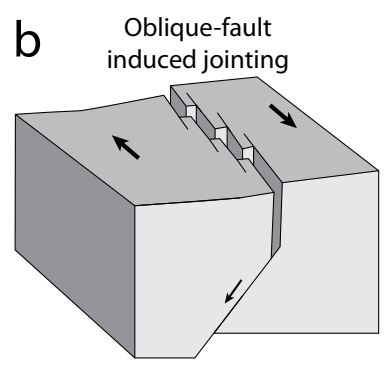

redrawn after Grant \& Kattenhorn (2004)

d Pre-existing joints

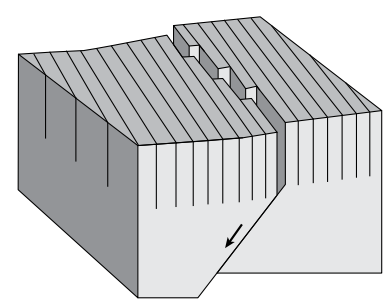

this study
Figure 17. Conceptual models illustrating different fault shapes according to the influence of preexisting joints. With no preexisting joints (a) faults show an irregular lateral fault shape resulting from fault segments growing together (after van Gent et al., 2010; Kettermann and Urai, 2015). (b) Joints forming due to oblique faulting are slightly inclined to the fault and limited in length. However, the fault shape can be very similar to the shown examples formed by preexisting joints (after Grant and Kattenhorn, 2004). (c) Fault localization at preexisting cooling joints in columnar basalts resemble the same process; however the fault shape is affected differently by the different joint pattern (after Gudmundsson, 1992). (d) A regular preexisting joint pattern as shown in this study strongly controls the fault shape but can look similar to case (b).

blocks. With preexisting joints the fault geometry is widely controlled by the joint pattern, as is the case in parts of Iceland or the Canyonlands. Figure 17 illustrates the effects of different prerequisites of a faulted region.

\subsection{Fault zone complexity}

Fault zones are usually complex in geometry and strain partitioning (McClay, 1990; Childs et al., 1996a, b; Walsh et al., 1999, 2003; Mansfield and Cartwright, 2001; Peacock, 2001, 2002; Wilkins and Gross, 2002; Soliva et al., 2008). For the Canyonlands grabens, Baker (1933) first described a graben-internal deformation by a number of graben-parallel faults in the downthrown blocks where they were exposed, although he did not define the location of his observations precisely. Walsh and Schultz-Ela (2003) showed field evidence from a cross section in Y Canyon, indicating at least one graben-internal fault and successfully compared this ob- 


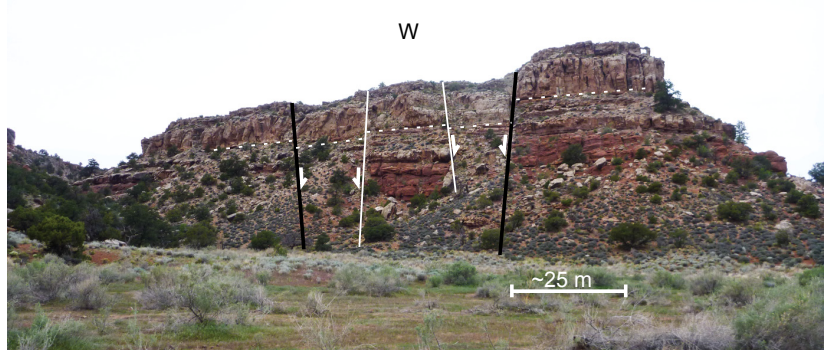

Figure 18. Graben in Cross Canyon. Black lines show main grabenbounding faults. White lines show two conjugate faults cutting through the graben floor. Dashed line illustrates marker horizon. Example for intra-graben faulting.

servation with numerical models. They also note incremental multiple faulting from aerial photographs.

This graben-internal faulting is consistent with our observations from Cross Canyon as illustrated in Fig. 18. The black lines depict the location of the main graben-bounding faults of this graben (for location see cross in Fig. 3), and the white lines show two conjugate faults affecting the graben floor. A number of GPR profiles in all three investigated grabens - i.e., Devil's Pocket (Fig. 14), Devil's Lane (Fig. 8) and Cyclone Canyon (Fig. 13) - reveal faulting in the grabens that is not visible at the surface. The faults in Devil's Pocket and northern Cyclone Canyon additionally show more than one fault strand. Our observations show that even flat and apparently undisturbed graben floors can contain complex fault systems. As these are not visible at the surface, the faults are presumably not active any more. The amount of grabeninternal faults might be slightly overestimated by GPR profiles since these faults propagate upwards from the brittle basement through several tens of meters of sediments in which the faults refract and form branches. The GPR profile in Devil's Lane for example shows several faults that do not reach to greater depth as well as some blind faults that are restricted in depth.

Combining all the information presented, we propose a model for the formation of a typical Canyonlands graben as shown in Fig. 19. Faults dip at $60-80^{\circ}$ and intersect the vertical joints. Hence, the outcropping graben walls are mostly joint surfaces rather than fault planes. Inclined faults reactivate the vertical joints at surface, and this change in fault dip forms large open voids at the graben walls, which are then filled with rockfall debris and sediments. Additional grabeninternal faulting causes a complex hard rock topography and requires reactive diapirism of the salt as also suggested by Schultz-Ela and Walsh (2002) and Walsh and Schultz-Ela (2003). As sinkholes are preferably found in the presumably younger grabens in the east and southeast and ponded deposits are observed in the presumably older western grabens (Cyclone Canyon), this might also be a criterion of graben

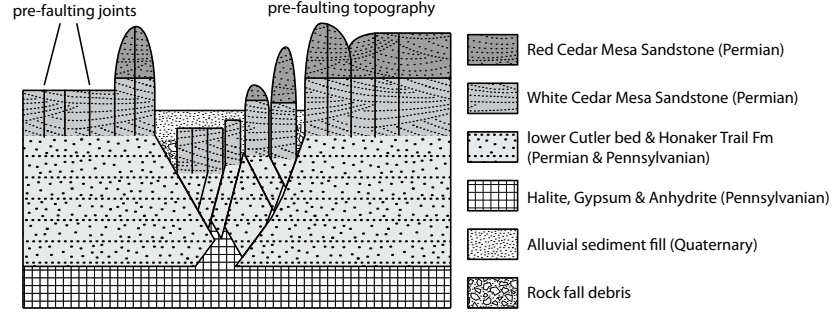

Figure 19. Schematic model of a typical Canyonlands graben from the northern section. Joints of the Cedar Mesa sandstones are reactivated by faulting. Shallower fault dips at depth cause open gaps at surface and secondary faulting within the grabens. Rockfall debris and alluvial sediments fill up open gaps and graben floors.

maturity. Similar models were proposed by Schultz-Ela and Walsh (2002) and Walsh and Schultz-Ela (2003) based on numerical modeling, albeit disregarding the vertical joint sets. We show the importance of the joints in the evolution of the fault system and extend their models by providing direct field evidence for all features, including the strong effect of the vertical joints from GPR profiles, field observation and remote sensing.

\subsection{Graben age vs. deposition rates}

The GPR profile of central Cyclone Canyon revealed detailed sedimentary structures to a depth of about $4 \mathrm{~m}$ (Fig. 13). We noticed three distinct horizons of horizontal reflectors and in between delta-like sequences of foreset beds and onlaps. The interpretation of lacustrine delta sediments is supported by typical layering of the dipping sediments, visible by changing reflector intensities, which implies sedimentation in water due to sudden events such as flash-floods. The geological map of Billingsley et al. (2002) shows that ponded deposits are common in Cyclone Canyon, and the authors state that these ponds were capable of sustaining water for several months to years. The thickness of the ponded deposits of up to $2 \mathrm{~m}$ fits well to the observed thickness in the radar profiles.

Especially the three horizontal layers that we interpret as paleosols fit very well to a graben fill east of Virginia Park, described and dated by Reheis et al. (2005). The location is marked with a black star in Fig. 3b. Thanks to the incision of a stream, they were able to visually study a soil profile down to $6 \mathrm{~m}$ depth and apply optically stimulated luminescence (OSL) dating. They described three paleosols: one close to the surface, one at $2 \mathrm{~m}$ depth and a third one at about $3 \mathrm{~m}$ depth. Dating right above the second paleosol results in an age of about 15-16 ka, and sediments above the third paleosol were dated to $27-28 \mathrm{ka}$. Figure 20 shows the GPR profile of the central Cyclone Canyon with the stratigraphic column and OSL ages of Reheis et al. (2005) as an overlay. The depths of all paleosols match, with deviation of only a few centimeters. 


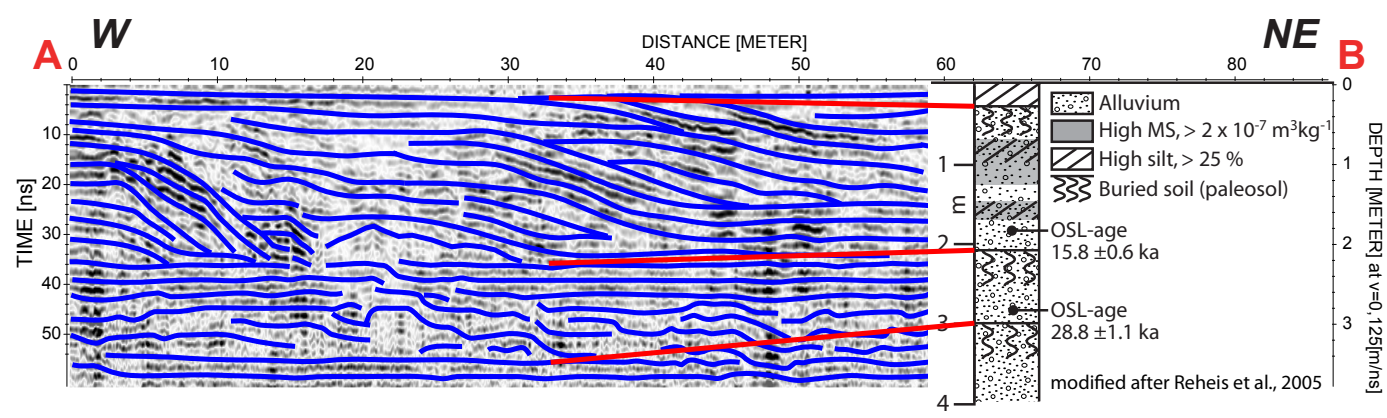

Figure 20. $400 \mathrm{MHz}$ profile of central Cyclone Canyon with overlay of the profile and OSL ages of Reheis et al. (2005). Three horizontal layers in the GPR profile fit well to paleosols from outcrop profile with an error of less than $0.5 \mathrm{~m}$.

Based on the proposed age of the grabens (Biggar and Adams, 1987; Schultz and Moore, 1996; Trudgill, 2002), the sediment thickness in Cyclone Canyon (Grosfils et al., 2003) and the known age of these paleosols (Reheis et al., 2005), we propose three possible scenarios of graben formation and sedimentation:

1. The horizons in GPR and outcrop are not the same. Still we would interpret the observed horizons as paleosols. Assuming a faster deposition rate in Cyclone Canyon due to its preferred role as a sediment trap would then suggest long-range climatic changes within the recorded $4 \mathrm{~m}$ of the profile and distinct differences in deposition over short distances.

2. The horizons in GPR and outcrop are the same. An explanation for the small discrepancy in the depth of the paleosols would be a faster sedimentation between the first and second paleosol. This is likely since Cyclone Canyon is a quite deep graben compared to the one east of Virginia Park and thus a better sediment trap. The delta-like foreset beds observed between the upper two paleosols indicate a high deposition rate in the presence of water, i.e., extensive flash floods as they occur from time to time, depositing in ponds. Additionally, slight differences in depth can result from imperfect timedepth conversion. Applying the OSL ages from Reheis et al. (2005) to the depths in Cyclone Canyon allows an estimation of sedimentation rates. The first OSL age of roughly $16 \mathrm{ka}$ at a depth of $2.2 \mathrm{~m}$ leads to a sedimentation rate of $0.14 \mathrm{~mm} \mathrm{a}^{-1}$ for this section. The distance between the second and third paleosol is approximately the same as in the Virginia Park graben - $1 \mathrm{~m}$ - and the age of about $28 \mathrm{ka}$ leads to a sedimentation rate of $0.08 \mathrm{~mm} \mathrm{yr}^{-1}$. Seismic refraction data (Abrahamson, 2005) suggest a sediment thickness of about $50 \mathrm{~m}$ at this location. Following the suggested ages of graben initiation of 65-85 ka (Campbell, 1987; Schultz and Moore, 1996), the deposition rates below the third paleosol must have been 1 order of magnitude higher. These would still be reasonable deposition rates but would suggest a drastic change in the deposition system at one point.

3. In the third case the paleosols are the same, a sediment package of $50 \mathrm{~m}$ is given and we assume that the rate of deposition has not changed dramatically in the past. That would point towards an earlier initiation of graben formation than previously estimated by termoluminescence dating of sediments found in sinkholes (Campbell, 1987), although their results may not apply for all grabens. Using a deposition rate of $0.15 \mathrm{~mm} \mathrm{a}^{-1}$ as an average for the remaining $47 \mathrm{~m}$ beneath our profile results in an age of about $300 \mathrm{ka}$. This is supported by comparing recent deformation rates with estimates of total strain in the Needles fault zone. Westwards movements of 3-9 $\mathrm{mm} \mathrm{a}^{-1}$ were proposed from InSAR data by Furuya et al. (2007). These fit to the GPS data of Marsic (2003), who reported $5 \mathrm{~mm} \mathrm{a}^{-1}$. According to Moore and Schultz (1999) a total extension of $1.29 \mathrm{~km}$ took place on the northern section of the grabens. Assuming an average extension of $5 \mathrm{~mm} \mathrm{a}^{-1}$ would require an age of graben initiation of about $260 \mathrm{ka}$, which would fit well to the observed sediment thickness and deposition rates. Schultz-Ela and Walsh (2002) used geomechanical numerical modeling to reproduce the grabens and proposed an age of $135 \mathrm{ka}$ for their models, which is younger than suggested here but still older than the previous estimates. Grosfils et al. (2003) in contrast calculated a smaller extension of about $2 \%$ in Devil's Lane and transferred this value to the other grabens, resulting in a total extension of about $100 \mathrm{~m}$ and an age fitting to the earlier estimates.

To resolve the remaining problems, more data are needed from different grabens and locations. Especially case (1) can only be validated or rejected by drilling in Cyclone Canyon and actually comparing and dating the sediments directly. However, it seems legitimate to assume an intermediate situation of cases (2) and (3). Some authors (Trudgill and Cartwright, 1994; Schultz-Ela and Walsh, 2002) propose graben initiation at $500 \mathrm{ka}$ or more, following the timing of 
the Colorado River incision. Higher deposition rates are also possible. A mixture of both would be a good explanation for the intermediate age of 260-300 ka proposed in our model.

\section{Conclusions}

Having applied ground-penetrating radar surveys combined with field observations in the Needles fault zone of Canyonlands National Park, Utah, USA, we draw the following conclusions:

1. Our GPR profiles revealed faults in the subsurface that were overprinted and not visible at the surface. We can therefore conclude that the fault zone of the Canyonlands grabens is more complex than obvious. Since this area is an analogue for reservoirs, knowledge of the fault zone complexity can be used to enhance seismic interpretation and fault zone permeability estimates.

2. Dilatant faulting is evident in many places, even if the surface expression is overprinted by sedimentation. Measurements of heave and throw at some faults additionally provide evidence for vertical fractures at the surface in combination with joint reactivation and inclined faults at depth.

3. We propose a model of graben formation based on our observations, including fault localization at tips of vertical joints, shallow fault dips at depth, graben-internal faulting and reactive diapirism.

4. Paleosols in the subsurface of Cyclone Canyon correlate with the climate reconstruction of Reheis et al. (2005). Comparing these paleosols, their ages and the underlying sediment thicknesses imply either a graben age older than expected from previous dating or higher sedimentation rates in Cyclone Canyon.

\section{The Supplement related to this article is available online at doi:10.5194/se-6-839-2015-supplement.}

Acknowledgements. We like to thank Marc Miller and Vicky Webster from the National Park Service for their kind support in the preparation of the field study. Further, we thank Andrea Billi and Fabrizio Balsamo for their helpful reviews.

Edited by: F. Rossetti

\section{References}

Abe, S., van Gent, H., and Urai, J. L.: DEM simulation of normal faults in cohesive materials, Tectonophysics, 512, 12-21, 2011.

Abrahamson, J.: Determining the thickness of sediments using seismic refraction, Cyclone Canyon Graben, Canyonlands National Park, Utah, in: 18th Annual Keck Research Symposium in Geology 2005, Colorado Springs, Colorado, USA, 7-10, 2005

Angelier, J., Bergerat, F., Dauteuil, O., and Villemin, T.: Effective tension-shear relationships in extensional fissure swarms, axial rift zone of northeastern Iceland, J. Struct. Geol., 19, 673-685, 1997

Baker, A. A.: Geology and oil possibilities of the Moab district, Grand and San Juan Counties, Utah, US Geological Survey Bulletin 841, Washington, D.C., 1993.

Balsamo, F., Storti, F., Piovano, B., Salvini, F., Cifelli, F., and Lima, C.: Time dependent structural architecture of subsidiary fracturing and stress pattern in the tip region of an extensional growth fault system, Tarquinia basin, Italy, Tectonophysics, 454, 54-69, 2008.

Biggar, N. E. and Adams, J. A.: Dates derived from Quaternary strata in the vicinity of Canyonlands National Park, in: Geology of Cataract Canyon and Vicinity: A Field Symposium - Guidebook of the Four Corners Geological Society, edited by: Campbell, J. A., Canyonlands Research Bibliography, 127-136, Paper No. 327, 1987

Billingsley, G. H., Block, D. L., and Felger, T. J.: Surficial geologic map of The Loop and Druid Arch quadrangles, Canyonlands National Park, Utah, US Geological Survey, available at: http: //ngmdb.usgs.gov/Prodesc/proddesc_54148.htm (last access: 12 March 2015), 2002

Campbell, J. A. (Ed.): Geology of Cataract Canyon and Vicinity: A Field Symposium - Guidebook of the Four Corners Geological Society, Canyonlands Research Bibliography. Four Corners Geological Society, Guidebook, 10th Field Conference, 1987.

Cartwright, J. A. and Mansfield, C. S.: Lateral displacement variation and lateral tip geometry of normal faults in the Canyonlands National Park, Utah, J. Struct. Geol., 20, 3-19, 1998.

Cartwright, J. A., Trudgill, B. D. and Mansfield, C. S.: Fault growth by segment linkage: an explanation for scatter in maximum displacement and trace length data from the Canyonlands Grabens of SE Utah, J. Struct. Geol., 17, 1319-1326, 1995.

Childs, C., Nicol, A., Walsh, J. J., and Watterson, J.: Growth of vertically segmented normal faults, J. Struct. Geol., 18, 13891397, 1996a.

Childs, C., Watterson, J., and Walsh, J. J.: A model for the structure and development of fault zones, J. Geol. Soc., 153, 337-340, $1996 b$.

Condon, S. M.: Geology of the Pennsylvanian and Permian Cutler Group and Permian Kaibab Limestone in the Paradox Basin, southeastern Utah and southwestern Colorado, Washington, US, G.P.O., 1997.

Crider, J. G. and Peacock, D. C. P.: Initiation of brittle faults in the upper crust: a review of field observations, J. Struct. Geol., 26 , 691-707, 2004.

Destro, N.: Release fault: A variety of cross fault in linked extensional fault systems, in the Sergipe-Alagoas Basin, NE Brazil, J. Struct. Geol., 17, 615-629, doi:10.1016/0191-8141(94)00088-H, 1995. 
Ehrenberg, S. N. and Nadeau, P. H.: Sandstone vs. carbonate petroleum reservoirs: A global perspective on porosity-depth and porosity-permeability relationships, AAPG Bull., 89, 435-445, 2005.

Ferrill, D. A. and Morris, A. P.: Dilational normal faults, J. Struct. Geol., 25, 183-196, 2003.

Ferrill, D. A., Wyrick, D. Y., Morris, A. P., Sims, D. W. and Franklin, N. M.: Dilational fault slip and pit chain formation on Mars, GSA Today, 14, 4-12, 2004.

Ferrill, D. A., Wyrick, D. Y., and Smart, K. J.: Coseismic, dilationalfault and extension-fracture related pit chain formation in Iceland: Analog for pit chains on Mars, Lithosphere, 3, 133-142, 2011.

Ferrill, D. A., McGinnis, R. N., and Morris, A. P.: Control of mechanical stratigraphy on bed-restricted jointing and normal faulting: Eagle Ford Formation, south-central Texas, AAPG Bull., 98, 2477-2506, 2014.

Fossen, H., Schultz, R. A., Rundhovde, E., Rotevatn, A., and Buckley, S. J.: 2010. Fault linkage and graben stepovers in the Canyonlands (Utah) and the North Sea Viking Graben, with implications for hydrocarbon migration and accumulation, AAPG Bull., 94, 597-613, 2010.

Furuya, M., Mueller, K., and Wahr, J.: Active salt tectonics in the Needles District, Canyonlands (Utah) as detected by interferometric synthetic aperture radar and point target analysis: 1992-2002, J. Geophys. Res., 112, B06418, doi:10.1029/2006JB004302, 2007.

Goldstrand, P. M.: Tectonic development of Upper Cretaceous to Eocene strata of southwestern Utah, Geol. Soc. Am. Bull., 106, 145-154, doi:10.1130/00167606(1994)106<0145:TDOUCT>2.3.CO;2, 1994.

Grant, J. V. and Kattenhorn, S. A.: Evolution of vertical faults at an extensional plate boundary, southwest Iceland, J. Struct. Geol., 26, 537-557, 2004.

Grosfils, E. B., Schultz, R. A., and Kroeger, G.: Geophysical exploration within northern Devils Lane graben, Canyonlands National Park, Utah: implications for sediment thickness and tectonic evolution, J. Struct. Geol., 25, 455-467, 2003.

Gudmundsson, A.: Formation and growth of normal faults at the divergent plate boundary in Iceland, Terra Nova, 4, 464-471, 1992.

Gudmundsson, A. and Bäckström, K.: 1991. Structure and development of the Sveinagja graben, Northeast Iceland, Tectonophysics, 200, 111-125, 1991.

Gutiérrez, F.: Origin of the salt valleys in the Canyonlands section of the Colorado Plateau, Geomorphology, 57, 423-435, 2004.

van Heteren, S., Fitzgerald, D. M., Mckinlay, P. A., and Buynevich, I. V.: Radar facies of paraglacial barrier systems: coastal New England, USA, Sedimentology, 45, 181-200, doi:10.1046/j.1365-3091.1998.00150.x, 1998.

Hintze, L. F., Willis, G. C., Laes, D. Y. M., Sprinkel, D. A., and Brown, K. D.: Digitial Geological Map of Utah. Utah Geological Survey in cooperation with the USGS, Salt Lake City, Utah, USA, 2000.

Holland, M., Urai, J. L., and Martel, S.: The internal structure of fault zones in basaltic sequences, Earth Planet. Sc. Lett., 248, 301-315, 2006.

Holland, M., van Gent, H. W., Bazalgette, L., Yassir, N., Hoogerduijn Strating, E. H., and Urai, J. L.: Evolution of dilatant frac- ture networks in a normal fault - Evidence from 4D model experiments, Earth Planet. Sc. Lett., 304, 399-406, 2011.

Huntoon, P. W.: The Meander anticline, Canyonlands, Utah: An unloading structure resulting from horizontal gliding on salt, Geol. Soc. Am. Bull., 93, 941-950, doi:10.1130/00167606(1982)93<941:TMACUA>2.0.CO;2, 1982.

Huntoon, P. W., Billingsley, G. H., and Breed, W. J.: Geologic map of Canyonlands National Park and vicinity, Canyonlands National History Assoc., Moab, Utah, 1982.

Jafari, A. and Babadagli, T.: Effective fracture network permeability of geothermal reservoirs, Geothermics, 40, 25-38, 2011.

Kattenhorn, S. A., Aydin, A., and Pollard, D. D.: Joints at high angles to normal fault strike: an explanation using 3-D numerical models of fault-perturbed stress fields, J. Struct. Geol., 22, 1-23, 2000.

Kettermann, M.: The Effect of Preexisting Joints on Normal Fault Evolution - Insights from Fieldwork and Analogue Modeling. MSc Thesis, RWTH Aachen University, Aachen, Germany, 2012.

Kettermann, M. and Urai, J. L.: Changes in structural style of normal faults due to failure mode transition: first results from excavated scale models, J. Struct. Geol., 74, 105-116, 2015.

Lewis, R. Q. and Campbell, R. H.: Geology and uranium deposits of Elk Ridge and vicinity, San Juan county, Utah, US Geolological Survey Professional Paper, Washinton D.C., USA, 69 pp., 1965.

Mansfield, C. and Cartwright, J.: Fault growth by linkage: observations and implications from analogue models, J. Struct. Geol., 23, 745-763, 2001.

Marsic, S. D.: Active Deformation at Canyonlands National Park: Distribution of Displacements Across the Grabens Using Spaceborne Geodesy. University of Southern California, Los Angeles, CA, USA, 2003.

McClay, K. R.: Extensional fault systems in sedimentary basins: a review of analogue model studies, Mar. Petrol. Geol., 7, 206233, 1990.

McGill, G. E. and Stromquist, A. W.: The grabens of Canyonlands National Park, Utah: Geometry, mechanics, and kinematics, J. Geophys. Res., 84, 4547, doi:10.1029/JB084iB09p04547, 1979.

McGill, G. E., Schultz, R. A., and Moore, J. M.: Fault growth by segment linkage: an explanation for scatter in maximum displacement and trace length data from the Canyonlands grabens of SE Utah: Discussion, J. Struct. Geol., 22, 135-140, 2000.

Mertens, J.: The fracture and fault system in the Grabens, Canyonlands National Park, Utah: Geological mapping and interpretation of tectonic history. Dipl. Mapping, RWTH Aachen University, Aachen, Germany, 2006.

Moore, J. M. and Schultz, R. A.: Processes of faulting in jointed rocks of Canyonlands National Park, Utah, Geol. Soc. Am. Bull., 111, 808-822, 1999.

National Agriculture Imagery Program, 1 Meter Orthophotography, available at: https://lta.cr.usgs.gov/NAIP (last access: 12 March 2015), 2009.

Neal, A.: Ground-penetrating radar and its use in sedimentology: principles, problems and progress, Earth-Sci. Rev., 66, 261-330, 2004.

Peacock, D. C. P.: The temporal relationship between joints and faults. J. Struct. Geol., 23, 329-341, 2001.

Peacock, D. C. P.: Propagation, interaction and linkage in normal fault systems, Earth-Sci. Rev., 58, 121-142, 2002. 
Peacock, D. C. P. and Sanderson, D. J.: Effects of layering and anisotropy on fault geometry, J. Geol. Soc., 149, 793-802, 1992.

Reheis, M. C., Reynolds, R. L., Goldstein, H., Roberts, H. M., Yount, J. C., Axford, Y., Cummings, L. S., and Shearin, N.: Late Quaternary eolian and alluvial response to paleoclimate, Canyonlands, southeastern Utah, Geol. Soc. Am. Bull., 117, 1051, doi:10.1130/B25631.1, 2005.

Rosentreter, R., Bowker, M., and Belnap, J.: A Field Guide to Biological Soil Crusts of Western U.S. Drylands - Common Lichens and Bryophytes, US Government Printing Office, Denver, Colorado, 104 pp., 2007.

Sandmeier, K. H.: Reflex-Win Version 6.0.5 radar processing and interpretation software, Sandmeier Scientific Software, Karlsruhe, Germany, 6.0.5, 2011.

Schöpfer, M. P. J., Childs, C., and Walsh, J. J.: Two-dimensional distinct element modeling of the structure and growth of normal faults in multilayer sequences: 2. Impact of confining pressure and strength contrast on fault zone geometry and growth, J. Geophys. Res., 112, B10404, doi:10.1029/2006JB004903, 2007a.

Schöpfer, M. P. J., Childs, C., and Walsh, J. J.: Two-dimensional distinct element modeling of the structure and growth of normal faults in multilayer sequences: 1 . Model calibration, boundary conditions, and selected results, J. Geophys. Res. 112, B10401, doi:10.1029/2006JB004902, 2007b.

Schöpfer, M. P. J., Childs, C., Walsh, J. J., Manzocchi, T., and Koyi, H. A.: Geometrical analysis of the refraction and segmentation of normal faults in periodically layered sequences, J. Struct. Geol., 29, 318-335, 2007c.

Schultz, R. A. and Moore, J. M.: New Observations of Grabens from the Needles District, Canyonlands National Park, Utah, in: Geology and Resources of the Paradox Basin, edited by: Huffman Jr., A. C., Lund, W. R., and Godwin, L. H., Utah Geological Association Guidebook, Salt Lake City, Utah, USA, 295-302, 1996.

Schultz-Ela, D. and Walsh, P.: Modeling of grabens extending above evaporites in Canyonlands National Park, Utah, J. Struct. Geol., 24, 247-275, 2002.

Smith, D. G. and Jol, H. M.: Ground penetrating radar: antenna frequencies and maximum probable depths of penetration in Quaternary sediments, J. Appl. Geophys., 33, 93-100, 1995.

Soliva, R., Benedicto, A., Schultz, R. A., Maerten, L., and Micarelli, L.: Displacement and interaction of normal fault segments branched at depth: Implications for fault growth and potential earthquake rupture size, J. Struct. Geol., 30, 1288-1299, 2008.
Trudgill, B. and Cartwright, J.: Relay-ramp forms and normal-fault linkages, Canyonlands National Park, Utah, Geolo. Soc. Am. Bull., 106, 1143-1157, 1994.

Trudgill, B. D.: Structural controls on drainage development in the Canyonlands grabens of southeast Utah, AAPG Bull., 86, 10951112, 2002.

Utah Automated Geographic Reference Center, HRO 1 Foot Color Orthophotography, available at: http://gis.utah.gov/data/ aerial-photography/52009-hro-1-foot-color-orthophotography (last access: 12 March 2015), 2009.

Van Gent, H. W., Holland, M., Urai, J. L., and Loosveld, R.: Evolution of fault zones in carbonates with mechanical stratigraphy - Insights from scale models using layered cohesive powder, J. Struct. Geol., 32, 1375-1391, 2010.

Walsh, J., Bailey, W.., Childs, C., Nicol, A., and Bonson, C.: Formation of segmented normal faults: a 3-D perspective, J. Struct Geol., 25, 1251-1262, 2003.

Walsh, J. J., Watterson, J., Bailey, W. R., and Childs, C.: Fault relays, bends and branch-lines, J. Struct. Geol., 21, 1019-1026, 1999.

Walsh, P. and Schultz-Ela, D. D.: Mechanics of graben evolution in Canyonlands National Park, Utah, Geol. Soc. Am. Bull., 115, 259-270, 2003.

Wennberg, O. P., Malm, O., Needham, T., Edwards, E., Ottesen, S., Karlsen, F., Rennan, L., and Knipe, R.: On the occurrence and formation of open fractures in the Jurassic reservoir sandstones of the Snohvit Field, SW Barents Sea, Petrol. Geosci., 14, 139$150,2008$.

Wilkins, S. J. and Gross, M. R.: Normal fault growth in layered rocks at Split Mountain, Utah: influence of mechanical stratigraphy on dip linkage, fault restriction and fault scaling, J. Struct. Geol., 24, 1413-1429, 2002.

Wong, I. G., Olig, S. S., and Bott, J. D. J.: Earthquake Potential and Seismic Hazards in the Paradox Basin, Southeastern Utah. Geology and Resources of the Paradox Basin: Utah Geological Association Guidebook 25, 241-251, Salt Lake City, Utah, USA, 1993. 